\title{
Arsenic Contamination of Groundwater: A Review of Sources, Prevalence, Health Risks, and Strategies for Mitigation
}

\author{
Shiv Shankar, ${ }^{1}$ Uma Shanker, ${ }^{2}$ and Shikha ${ }^{1}$ \\ ${ }^{1}$ Babasaheb Bhimrao Ambedkar University, Lucknow 226025, India \\ ${ }^{2}$ Department of Chemistry, Dr. B. R. Ambedkar National Institute of Technology Jalandhar, Punjab 144011, India
}

Correspondence should be addressed to Uma Shanker; umaorganic29@gmail.com

Received 2 July 2014; Accepted 17 August 2014; Published 14 October 2014

Academic Editor: Andrei Surguchov

Copyright (C) 2014 Shiv Shankar et al. This is an open access article distributed under the Creative Commons Attribution License, which permits unrestricted use, distribution, and reproduction in any medium, provided the original work is properly cited.

\begin{abstract}
Arsenic contamination of groundwater in different parts of the world is an outcome of natural and/or anthropogenic sources, leading to adverse effects on human health and ecosystem. Millions of people from different countries are heavily dependent on groundwater containing elevated level of As for drinking purposes. As contamination of groundwater, poses a serious risk to human health. Excessive and prolonged exposure of inorganic As with drinking water is causing arsenicosis, a deteriorating and disabling disease characterized by skin lesions and pigmentation of the skin, patches on palm of the hands and soles of the feet. Arsenic poisoning culminates into potentially fatal diseases like skin and internal cancers. This paper reviews sources, speciation, and mobility of As and global overview of groundwater As contamination. The paper also critically reviews the As led human health risks, its uptake, metabolism, and toxicity mechanisms. The paper provides an overview of the state-of-the-art knowledge on the alternative As free drinking water and various technologies (oxidation, coagulation flocculation, adsorption, and microbial) for mitigation of the problem of As contamination of groundwater.
\end{abstract}

\section{Introduction}

Contamination of groundwater, either from anthropogenic or natural sources with several social impacts, has now turned to be a major environmental concern in different parts of the world. Millions of people in several countries are exposed to high levels of As via intake of As-rich groundwater. Elevated level of As in groundwater has been well documented in Chile, Mexico, China, Argentina, USA, and Hungary $[1,2]$ as well as in the Indian State of West Bengal, Bangladesh, and Vietnam [2-6]. About 150 million people around the world are estimated to be affected globally with an increasing prospect as new affected areas are continuously discovered [7]. Arsenic, a well-known carcinogen, is considered as one of the world's most hazardous chemicals [8]. Excessive and longterm (such as 5-10 years) human intake of toxic inorganic As from drinking water and food may result in arsenicosis, a common name generally used for As related health problems including skin disorders, skin cancers, internal cancers (bladder, kidney, and lung), diseases of the blood vessels of the legs and feet, possibly diabetes, increased blood pressure, and reproductive disorders [9-11].

In terrestrial environment, the inorganic forms of As (such as trivalent arsenite $\left(\mathrm{As}^{\mathrm{III}}\right)$ and pentavalent arsenate $\left.\left(\mathrm{As}^{\mathrm{V}}\right)\right)$ are more prevalent and toxic than the organic forms in general. As exerts detrimental effects on general protein metabolism with high toxicity by reacting with sulfhydryl groups existing in cysteine residues [12].

Arsenicosis causes dire consequences for the livelihood, family life, and earning capability when individuals fall victim. Deterioration in physical appearance makes women socially excluded. At larger perspectives elevated As contamination of a region may result in societal stress, disability in individuals, poverty, and decreased market value of potentially contaminated agricultural products leading to low income to the affected farmers [13]. Absence of taste, odour, colour, and exposure make As impossible for a layman to detect and avoid. Applying the WHO provisional guideline 
for drinking water of $10-50 \mathrm{ppb}$ of As, a population of more than 100 million people worldwide is at risk, and of these more than 45 million people mainly in developing countries from Asia are at risk of being exposed to more than $50 \mathrm{ppb}$ of As, which is the maximum concentration limit in drinking water in most of the countries in Asia [7].

At present, As is estimated to affect more than 150 million people worldwide with its increasingly elevated concentrations in drinking water [14]. The major arsenicosis affected areas have been reported in large deltas and/or along major river basins across the world [15] such as in Paraiba do Sul delta, Brazil [16], Bengal delta [17-19], Mekong delta, Cambodia [20], Danube river basin, Hungry [21], Hetao river basin, Mongolia [22], Duero Cenozoic Basin, Spain [23], Zenne river basin, Belgium [21], and Tulare Lake, USA [24]. The transfer of As to the food chain will ultimately remain as long-term risks to human and ecological systems [25]. Since water is the principal route through which As enters into the human body [26], the understanding of the processes of As contamination in groundwater, associated health risks, and mitigation of As problem is required.

The present review summarizes possible sources of As contamination of groundwater, global overview of groundwater As contamination, toxicity, basic chemistry, associated health risks, and the best available strategies for mitigation of As pollution in groundwater.

\section{Sources, Speciation, and Mobility of As in Groundwater}

Several natural and anthropogenic sources are deemed responsible for As contamination in groundwater. As occurs as a major constituent in more than 200 minerals [27] and the desorption and dissolution of naturally occurring As bearing minerals and alluvial sediments result in high As concentration in groundwater in deltas and alluvial plains even if the As concentration in the solid phase is not high $[28,29]$. The presence of metalloid in excess concentration in groundwater may be associated with ore deposits where As is present predominantly in sulfidic minerals such as arsenopyrite and pyrite [30]. Arsenopyrite (FeAsS) is the most abundant As containing mineral generally existing in anaerobic environments and in various other rock forming minerals like sulfide, oxide, phosphate, carbonate, and silicate [1]. It is present as a substitute of $S$ in the crystal lattice of various sulfide minerals. Realgar $\left(\mathrm{As}_{4} \mathrm{~S}_{4}\right)$ and orpiment $\left(\mathrm{As}_{2} \mathrm{~S}_{3}\right)$ represent the two common reduced forms of As while in arsenolite $\left(\mathrm{As}_{2} \mathrm{O}_{3}\right)$, As is present in oxidized form [21]. Depending on the nature and texture of minerals, As can also be found in sediments, in the concentration range from 3 to $10 \mathrm{mg} \mathrm{kg}^{-1}$ [7]. The areas with high concentrations of Fe oxide or hydrous metal oxide or pyrites contain very high levels of As in sediments in comparison to other oxides. In reducing sediments, the concentration of As is found to be high; the concentration of As increases gradually with increase in the depth of the sediment [31]. Fe and Al oxides present in sediments play a significant role for the contamination of groundwater. Reductive dissolution of $\mathrm{Fe}$ and $\mathrm{Al}$ metal oxides along with the activity of indigenous metal reducing bacteria is now deemed as the prominent release mechanism of As, directly effecting the mobility of As $[32,33]$. The main anthropogenic sources for contamination of groundwater with As are mining, burning of fossil fuels, use of arsenical fungicides, herbicides and insecticides in agriculture, and wood preservatives [21]. Burning of coal has profound effect on contamination of As in the environment. Emission of As takes place in the environment by volatilization of $\mathrm{As}_{4} \mathrm{O}_{6}$ due to burning of coal, which condenses in the flue system and ultimately transferred into water reservoirs [27]. The degree of groundwater arsenic contamination by aforesaid anthropogenic sources is much less as compared to the natural sources; however, their contribution cannot be neglected.

Arsenic in groundwater exists primarily as oxy anions representing two oxidation states: arsenic (arsenite) and arsenic (+V) (arsenate) [34, 35]. Arsenic in groundwater exists primarily as oxy anions representing two oxidation states: arsenic As ${ }^{\mathrm{III}}$ (arsenite) and arsenic As ${ }^{\mathrm{V}}$ (arsenate) [34, 35]. Both $\mathrm{As}^{\mathrm{III}}$ and $\mathrm{As}^{\mathrm{V}}$ exist within the $\mathrm{pH}$ range of 6-9. The predominant As ${ }^{\mathrm{III}}$ species are uncharged $\mathrm{H}_{3} \mathrm{AsO}_{3}$ while the primary arsenate species are monovalent $\mathrm{H}_{2} \mathrm{AsO}^{-4}$ and divalent $\mathrm{HAsO}_{2}{ }^{-4}$. Geology and groundwater environment make one form, either $A s^{\mathrm{III}}$ or $A s^{\mathrm{V}}$ dominant $[36,37]$. Although $\mathrm{As}^{\mathrm{V}}$ is thermodynamically favored in oxic waters and $A s^{\text {III }}$ in anoxic waters, they have been also reported to coexist in both types of waters [38, 39]. Many researches of localized studies [40-43] have reported the value of arsenic speciation information in explaining and understanding the behavior and characteristics of arsenic in the environment (solubility, mobility, etc.). The toxicity and the removability of arsenic differ between $\mathrm{As}^{\mathrm{III}}$ and $\mathrm{As}^{\mathrm{V}}$. As ${ }^{\mathrm{III}}$ is considered to be more toxic and more difficult to remove from water than $\mathrm{As}^{\mathrm{V}}$ [8]. The variability of the arsenic concentration in groundwater is ascribed to the arsenic content of the aquifer and the varying dissolution/desorption processes releasing the arsenic from the solid phase into the liquid phase [36, 37, $44,45]$. Reductive dissolution of Fe oxides is considered as the principal cause of As release from aquifer sediments [46].

\section{Global Overview of Groundwater Arsenic Contamination}

The contamination of As can be propagated defectively into the groundwater system because As in groundwater and aquifers is mobilized (e.g., hydraulic fracturing). Hence, its contamination can affect a large population of people [47].

Groundwater concentration of As has been documented in the literature which reveals a very large range from less than 0.5 to $5000 \mathrm{ppb}$ covering natural As contamination found in more than 70 countries [7]. Some of the best reported and most severe cases of arsenic contaminated groundwater have been found in aquifers across the globe which has been cited in Table 1. It represents that provisional guideline values for As concentration in groundwater are commonly set at $10 \mathrm{ppb}$, although it can reach up to $50 \mathrm{ppb}$. The outcomes of this comparison affirm that As contamination is a widespread global phenomenon and severe enough 
TABLE 1: Status of As contamination in natural groundwater in various countries.

\begin{tabular}{|c|c|c|c|c|c|}
\hline $\begin{array}{l}\text { Serial } \\
\text { number }\end{array}$ & Country & Region & Groundwater As level (ppb) & $\begin{array}{l}\text { Permissible } \\
\text { limit (ppb) }\end{array}$ & References \\
\hline 1 & Afghanistan & Ghazni & $10-500$ & 10 (WHO) & [21] \\
\hline 2 & Australia & $\begin{array}{l}\text { Victoria (around the } \\
\text { gold-mining regions) }\end{array}$ & $\begin{array}{l}\text { 1-12 (Groundwater); } \\
\text { 1-73 (Drinking-water); } \\
\text { 1-220 (Surface water) }\end{array}$ & - & {$[17,21,216]$} \\
\hline 3 & Bangladesh & Noakhali & $<1-4730$ & 50 (WHO) & {$[18,21,217]$} \\
\hline 4 & Brazil & $\begin{array}{c}\text { Minas Gerais } \\
\text { (Southeastern Brazil) }\end{array}$ & $\begin{array}{c}0.4-350 \\
\text { (Surface water) }\end{array}$ & 10 (WHO) & {$[17,216,218]$} \\
\hline 5 & Cambodia & $\begin{array}{c}\text { Prey Veng and } \\
\text { Kandal-Mekong delta }\end{array}$ & $\begin{array}{l}\text { Up to } 900 \\
1-1610\end{array}$ & $10(\mathrm{WHO})$ & {$[20,21]$} \\
\hline 6 & Canada & $\begin{array}{c}\text { Nova Scotia } \\
\text { (Halifax county) }\end{array}$ & $1.5-738.8$ & 10 (WHO) & {$[17,21]$} \\
\hline 7 & China & - & $50-4440$ & $50(\mathrm{WHO})$ & {$[219]$} \\
\hline 8 & Finland & Southwest Finland & $17-980$ & $10(\mathrm{WHO})$ & {$[17,216,218]$} \\
\hline 9 & Greece & $\begin{array}{c}\text { Fairbanks } \\
\text { (mine tailings) }\end{array}$ & Up to 10,000 & $10(\mathrm{WHO})$ & {$[1,21]$} \\
\hline 10 & India & $\begin{array}{l}\text { West Bengal } \\
\text { Uttar Pradesh }\end{array}$ & $10-3200$ & $50(\mathrm{WHO})$ & {$[1,21,216,220,221]$} \\
\hline 11 & Japan & $\begin{array}{l}\text { Fukuoka Prefecture } \\
\text { (southern region) }\end{array}$ & $1-293$ & 10 (WHO) & {$[17,216]$} \\
\hline 12 & Mexico & Lagunera & $8-620$ & 25 & {$[1,21,216]$} \\
\hline 13 & Nepal & Rupandehi & Up to 2620 & 50 & {$[21,219,222]$} \\
\hline 14 & Pakistan & $\begin{array}{c}\text { Muzaffargarh } \\
\text { (southwestern Punjab) }\end{array}$ & Up to 906 & 50 & {$[17,22,216]$} \\
\hline 15 & Taiwan & - & $10-1820$ & 10 (WHO) & {$[1,21,216]$} \\
\hline 16 & Thailand & Ron Phibun & $1->5000$ & 10 (WHO) & {$[1,21,216]$} \\
\hline 17 & USA & Tulare Lake & Up to 2600 & 10 (USEPA) & {$[21,24,223]$} \\
\hline 18 & Vietnam & $\begin{array}{c}\text { Red River Delta } \\
\text { (Northern Vietnam) } \\
\text { Mekong Delta } \\
\text { (Southern Vietnam) }\end{array}$ & $<1-3050$ & 10 (WHO) & {$[1,219]$} \\
\hline
\end{tabular}

exceeding such guideline values. In fact, people consuming As-rich water for prolonged periods are reported to suffer from serious health problems in many parts of the world.

\section{Arsenic: Health Risks}

Arsenic contamination in the environment is turning to be a serious public health problem in several parts of the world. It is well-established fact that arsenite $\mathrm{As}^{\mathrm{III}}$ is more toxic than arsenate $\mathrm{As}^{\mathrm{V}}$, with inorganic As being more toxic than organic As [48]. However, different organic As species represent different degrees of toxicity. For instance, monomethylarsonic acid $\left(\mathrm{MMA}^{\mathrm{V}}\right)$ and dimethylarsinic acid $\left(\mathrm{DMA}^{\mathrm{V}}\right)$ as final As metabolites are less toxic than inorganic arsenic, whereas the degrees of toxicity of intermediate metabolites such as monomethylarsonous acid $\left(\mathrm{MMA}^{\mathrm{III}}\right)$ and dimethylarsinous acid $\left(\mathrm{DMA}^{\mathrm{III}}\right)$ are much more higher than inorganic arsenic. The toxicity of various arsenic species increases in the order of $\mathrm{As}^{\mathrm{V}}<\mathrm{MMA}^{\mathrm{V}}<\mathrm{DMA}^{\mathrm{V}}<\mathrm{As}^{\mathrm{III}}<$ $\mathrm{MMA}^{\mathrm{III}} \approx \mathrm{DMA}^{\mathrm{III}}[48]$.
4.1. Uptake and Metabolism of Arsenic. In terrestrial environment, As is mainly present as inorganic As, which exists as pentavalent $\left(\mathrm{As}^{\mathrm{V}}\right)$ under aerobic condition and trivalent $\left(\mathrm{As}{ }^{\mathrm{III}}\right)$ under anaerobic environment $[28]$. As ${ }^{\mathrm{III}}$ is generally found as a neutral species $\left(\mathrm{As}(\mathrm{OH})_{3}^{\circ}, \mathrm{pKa}=9.2\right)$ in aqueous solution at physiological $\mathrm{pH}$. $\mathrm{As}^{\mathrm{III}}$ and $\mathrm{As}^{\mathrm{V}}$ cause toxicity differently [49]. Due to its structural similarity to glycerol, $\mathrm{As}^{\mathrm{III}}$ can be transported into cells through aquaglyceroporins, a pore protein for transporting small organic compounds such as glycerol and urea [50]. However, $\mathrm{As}^{\mathrm{V}}$ takes different pathway into animals and human cells. As a phosphate analog, they have similar dissociation constants (pKa of arsenic acid: 2.26, 6.76, and 11.3 and pKa of phosphoric acid: 2.16, 7.21, and 12.3) [51]. Similar to phosphate, $\mathrm{As}^{\mathrm{V}}$ is found in water as an oxy anions in solution, that is, $\mathrm{H}_{2} \mathrm{AsO}_{2}{ }^{-}$ and $\mathrm{HAsO}_{2}{ }^{2-}$ at $\mathrm{pH} 5-7$. As chemical analogs, they compete for their entry via phosphate transporters [52]. Having entered into the human and animal cells, $\mathrm{As}^{\mathrm{V}}$ is rapidly reduced to $\mathrm{As}^{\mathrm{III}}$. Thereafter, $\mathrm{As}^{\mathrm{III}}$ undergoes multisteps in cells through arsenite methyltransferase (AS3MT) using Sadenosylmethionine (SAM) as the methyl donor, resulting 
in the formation of methylated As compounds including $\mathrm{MMA}^{\mathrm{III}}, \mathrm{DMA}^{\mathrm{III}}, \mathrm{MMA}^{\mathrm{V}}$, and $\mathrm{DMA}^{\mathrm{V}}$ [53]. Challenger [54] first proposed the classical pathway of As methylation. He proposed that arsenic methylation involves a chain of oxidation and reduction steps (Figure 1(a)). Thereafter, Zakharyan and Aposhian [55] suggested that As ${ }^{\mathrm{III}}$ can be methylated nonenzymatically in the presence of both methylcobalamin and glutathione (GSH) (Figure 1(b)). In several studies later on, researchers extensively explored the mechanism of arsenic methylation and concluded that the enzymes play crucial role in arsenic methylation. A new enzymatic metabolic pathway for arsenic methylation has been shown in Figure 1(c). The $-\mathrm{OH}$ groups of $\mathrm{As}(\mathrm{OH})_{3}$ are substituted by glutathionyl moieties, leading to the formation of GSH conjugates As (GS) $)_{2}-\mathrm{OH}$ and $\mathrm{As}(\mathrm{GS})_{3}$ [56]. Afterwards, as the major substrates for AS3MT, As ${ }^{\text {III }}$-glutathione complexes are further methylated to monomethylarsonic diglutathione MMA (GS) ${ }_{2}$ and dimethylarsinic glutathione DMA (GS). Since DMA (GS) is unstable, it is immediately oxidized to pentavalent $\mathrm{DMA}^{\mathrm{V}}$, which is the major metabolite and is excreted from cells [57].

Naranmandura et al. [58] demonstrated a different pathway of arsenic metabolism via investigating the hepatic and renal metabolites of arsenic after an intravenous injection of $A s^{\mathrm{III}}$ in rats (Figure $1(\mathrm{~d})$ ). They asserted that $\mathrm{As}{ }^{\mathrm{III}}$ confined to the proteins (AsS3 protein) is metabolized in the body at the time of successive reductive methylation by AS3MT in the presence of GSH and SAM and the reduced metabolites are excreted outwardly. Consistent with the mechanisms, both trivalent and pentavalent inorganic and organic arsenicals were detected in the urine of individuals after chronic exposure to arsenic and in cell culture medium followed by in vitro exposure to arsenic [59].

4.2. Toxicity of Arsenic. Several review articles have documented arsenic toxicity in humans and animals (Figure 2). Arsenic is a potent carcinogen, leading to skin, bladder, liver, and lung cancers [60,61]. Arsenic induces epidemiological toxicity. It results in the formation of excess ROS thereby damaging organisms $[62,63]$. Arsenic is also known to cause cytotoxicity $[64,65]$ and genotoxicity $[66,67]$. In addition, it is well-established fact that chronic exposure to arsenic can lead to arsenicosis, including skin lesions, blackfoot disease, peripheral vascular disease, and cancers. However, several studies have reported arsenicosis due to elevated level of As [68].

4.2.1. Epidemiology. As a well-known human carcinogen, Asinduced mechanism of carcinogenesis has been extensively explored in several studies. Mounting evidences have demonstrated that arsenic hinders a series of gene proliferation processes (e.g., DNA damage and repair, cell cycle, and differentiation) and distorts signal transduction pathways (e.g., protein 53 signaling pathway, Nrf2-mediated redox signaling pathway, and MAPK pathway) $[69,70]$. ROS formation induced by As also plays a crucial role in triggering off cancer [71]. Further, investigations were of the opinion that methylation metabolites of arsenic are also potent carcinogens. Wei et al. [72] demonstrated that DMA causes cancer of urinary bladder in rats. Besides being well-known carcinogen, arsenic also causes a number of noncancerous multisystemic diseases including cardiovascular disease, dermal disease, hypertension, and diabetes mellitus [73,74]. Researchers have pointed out that trivalent arsenicals (As ${ }^{\mathrm{III}}, \mathrm{MMA}^{\mathrm{III}}$, and DMA ${ }^{\mathrm{III}}$ ) can induce diabetes via distortion of glucose metabolism based on intact pancreatic islets from mice $[75,76]$. In addition, As led inhibition of pyruvate and $\alpha$-ketoglutarate dehydrogenases has been found to be the principal cause of diabetes [77]. Cardiovascular diseases are closely linked with hypertension. There are several pathways for arsenic-induced hypertension, including promotion of inflammation activity and endothelial dysfunction, alteration of vascular tone in blood vessels, and malfunctioning of kidney [78]. In addition, several researchers were on the consensus that ROS's role in As-induced noncarcinogenic effects cannot be discounted $[79,80]$. Arsenic-induced ROS has been correlated with alteration in cell signaling, apoptosis, and increase in cytokine production, leading to inflammation, which in turn results in formation of more ROS and mutagenesis, contributing to pathogenesis of arsenic-induced diseases [81].

4.2.2. Cytotoxicity. Cytotoxicity develops when cell represents anomalies caused by toxic chemicals/contaminants. Arsenic led cytotoxicity in cells via several pathways has been explored by several researchers [82, 83]. Arsenic induces cytotoxicity by generating ROS [84]. ROS levels inside the cell increase dramatically when cell is exposed to elevated level of As. Arsenic results in ROS production by inducing NADPH oxidase [85]. Excess ROS causes damage in lipids and proteins as well as facilitating mitochondrial damage and its functions [86, 87]. Shen et al. [88] found that ROS-induced oxidative stress is caused by a mitochondria dependent apoptotic pathway. It has been well documented that ROS exerts cytotoxic effects by activating c-Jun $\mathrm{N}$-terminal kinases (JNK), an important subgroup of the mitogen-activated protein kinases, which intercedes diverse cellular functions such as cell proliferation, differentiation, and apoptosis [89]. In addition, ROS can also act as modulators of signal transduction pathways, affecting various biological processes including cell growth, apoptosis, cell adhesion, and HIV activation [90, 91]. Arsenic results in cytotoxicity by affecting the status of tumorsuppressor protein $53[92,93]$. Protein 53 plays a very crucial role in a wide range of cellular functions by modulation of transformation and regulation of cell growth and control of cell cycle, DNA synthesis, DNA repair and differentiation, and apoptosis [94, 95]. Yih and Lee [93] reported that arsenic may induce protein 53 accumulation in human fibroblasts, which ultimately results in cell apoptosis by promoting Bax translocation from the cytoplasm to the mitochondria, releasing cytochrome $c$ and activating caspase- 9 through Apaf-1 and the apoptosome [96, 97]. In addition, protein 53 can also result in inducement of cell cycle arrest at G2/M stage of the cell cycle by transcriptionally activating protein 21 , the inhibitor of cyclin-dependent kinases [98, 99], and may induce autophagy in a DRAM (damage-regulated autophagy modulator) dependent manner [100]. 


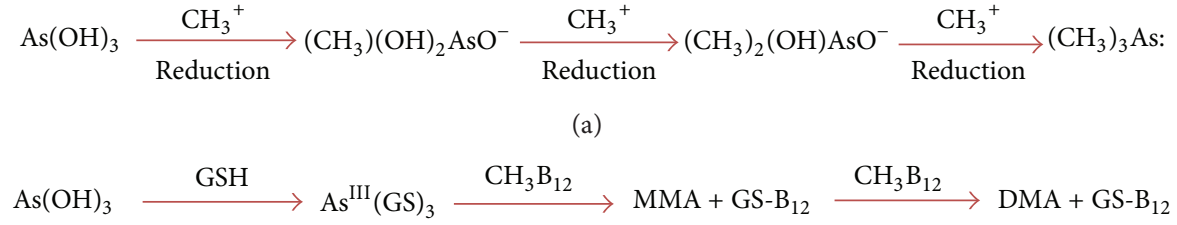

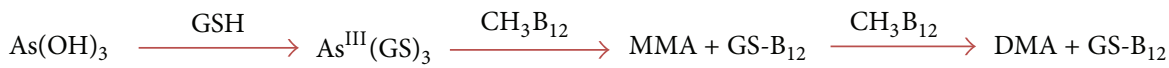

(b)

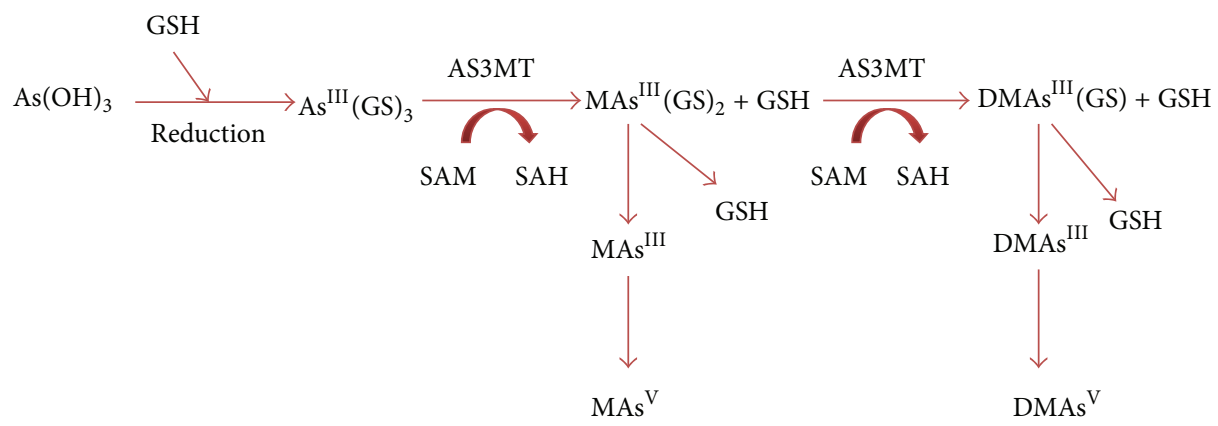

(c)

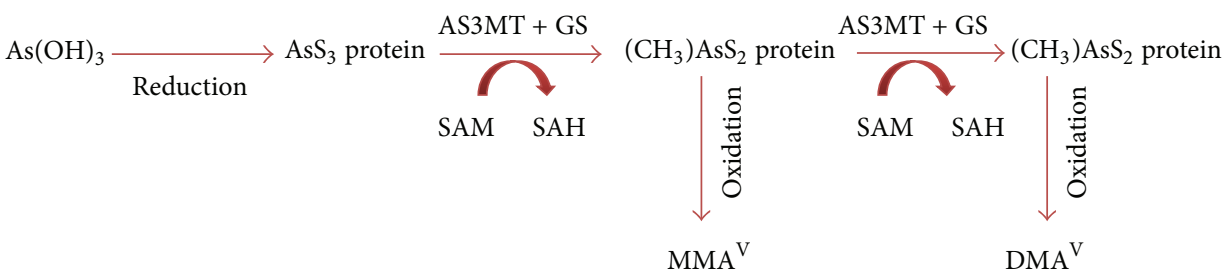

(d)

FIgURE 1: Pathways of arsenic metabolism in cells: (a) arsenic methylation in Scopulariopsis brevicaulis [54], (b) nonenzymatic As methylation in rat liver [55], (c) arsenic metabolic pathway in rat liver [56], and (d) metabolic pathway in rat liver [58], where SAM: Sadenosylmethionine; $\mathrm{SAH}$ : S-adenosylhomocysteine; $\mathrm{CH}_{3}{ }^{+}$: methyl group; $\mathrm{GSH}$ : glutathione; $\left(\mathrm{CH}_{3}\right)(\mathrm{OH})_{2}$ AsO ${ }^{-}$: monomethylarsonous acid; $\left(\mathrm{CH}_{3}\right)_{2}(\mathrm{OH}) \mathrm{AsO}^{-}$: dimethylarsinic acid; $\left(\mathrm{CH}_{3}\right)_{3}$ As: trimethyl arsine oxide; As $(\mathrm{GS})_{3}$ : arsenic triglutathione; MMA: monomethylarsonic acid; DMA: dimethylarsinic acid; MAs ${ }^{\mathrm{III}}(\mathrm{GS})_{2}$ : monomethylarsonic diglutathione; DMAs ${ }^{\mathrm{III}}$ (GS): dimethylarsinic glutathione; DMAs ${ }^{\mathrm{III}}$ : trivalent monomethylarsonous acid; $\mathrm{DMAs}^{\mathrm{V}}$ : pentavalent dimethylarsinic acid; $\mathrm{MMA}^{\mathrm{V}}$ : pentavalent monomethylarsonic acid [224].

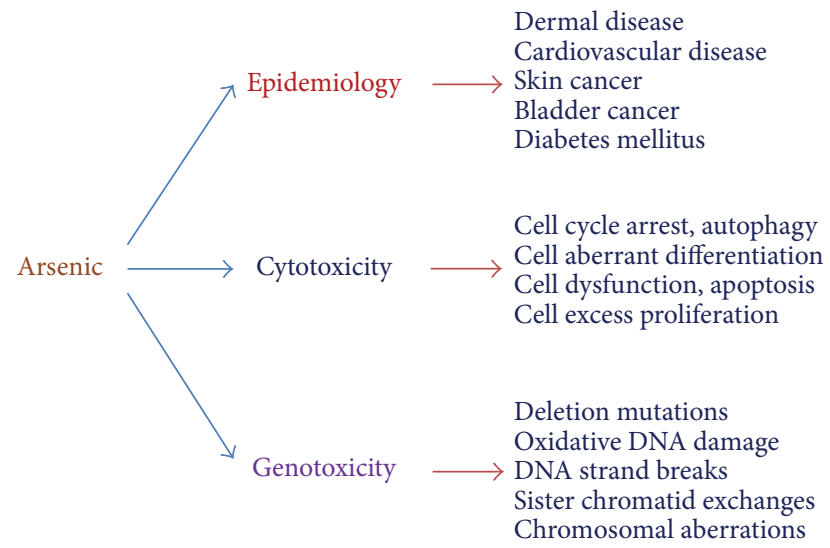

FIGURE 2: Arsenic toxicity in humans and rats [224].

4.2.3. Genotoxicity. Damage of genetic information inside the cell results in genotoxicity which ultimately leads to mutation. Till date, there are several studies addressing the genotoxicity of As [101, 102]. As induces genotoxicity by generating ROS in similar fashion as cytotoxicity [103]. ROS present in excess amount within the cell reacts with cellular components and result in genotoxicity. Genotoxicity occurs since ROS reacts with both deoxyribose and bases in DNA, causing base lesions and strand breaks. In addition, ROS are also involved in oxidation of DNA, alteration of DNA repair, gene regulation mechanism, and threatening of gene stability [104]. As interacts with DNA repair proteins possessing functional zinc finger motifs, which are involved in transcription, DNA repair proteins, and DNA-protein and protein-protein binding $[105,106]$. Zhou et al. [106] reported that As ${ }^{\mathrm{III}}$ affects zinc fingers by binding with its target molecule PARP-1, ultimately leading to breaks of single-strand and doublestrand of DNA and oxidative DNA damage [107]. Studies have found that arsenic can directly affect DNA repairing efficiency by lowering repair and expression of the nucleotide excision repair pathway member ERCC1 [108, 109]. Chronic exposure of cells to elevated level of arsenic can also result in induction of SAM depletion in cells, leading to loss of DNA methylation, and subsequently DNA hypomethylation in turn affects the genomic instability [110, 111]. Moreover, arsenic and trivalent methylated arsenic have been reported to interact with enzymes of SAM synthesis pathways $[112,113]$. 
This is in agreement with Zhong and Mass [114] who affirmed that As ${ }^{\mathrm{II}}$ or its metabolites can alter the activities of DNA methyltransferases and subsequently inhibit or stimulate the enzymes of SAM synthesis pathways. Similar to cytotoxicity, arsenic can also cause genotoxicity by affecting the status of protein 53 [115].

\section{Mitigation of As Problem: Assessment of Technological Solutions}

Selection of appropriate method to supply water with reduced As content relies on several factors and is complicated as the majority of the affected population lives in rural areas deprived off infrastructure and with decentralized water supplies from millions of shallow tube wells (STW) extracting water from shallow aquifers. Mitigation strategies for As contamination problem in groundwater therefore should address both technological and the socioeconomic considerations [116]. The various available options suited for getting drinking water with low As content can be divided into two categories which include

(i) finding an alternative As free water source,

(ii) removal of As from the existing water source.

\subsection{Alternative for Free Water Sources}

5.1.1. Deep Groundwater. Literature reviews from the Bengal and the Mekong deltas insinuate that As-rich water occurs mainly in the shallow groundwater, whereas groundwater from deeper aquifers is almost completely free from As. For example, the study by BGS revealed that only $5 \%$ of the deep tube well (>150 m deep) waters had As concentrations above $10 \mathrm{ppb}$ and $1 \%$ exceeded the $50 \mathrm{ppb}$ [117]; thus, water supply relying on manually operated deep tube wells (DTW) could be an appropriate source. However, the depth to Asfree aquifers differs between the locations. For example, in the Bengal delta, generally water extraction below 150/200 m deep is considered as deep aquifer, but in many cases this can be below $200 \mathrm{~m}$ [118]. However, in the Red River and the Mekong deltas, As concentration is low at depths at only $>50 \mathrm{~m}$ and $>70 \mathrm{~m}$ [119]. The major restriction to the deep water extraction option is its costly installation, leading to its applicability only on community basis. Some other drawbacks to this option include availability of the As free deep aquifer, the uncertainty of the groundwater recharge mechanism [120], the risk of salt water intrusion in coastal areas, and very high concentrations of dissolved $\mathrm{Fe}$ and $\mathrm{Mn}$ [121]. Mn and Fe cause obnoxious taste and stains in water and laundry even at quite low concentrations exceeding $100 \mathrm{ppb}$. The permissible limit of Mn for same human health in groundwater for $\mathrm{Mn}$ is $400 \mathrm{ppb}$ [9].

5.1.2. Shallow Groundwater (Well Switching). The As contamination in the shallow groundwater varies greatly [1] and the countywide study by British Geological Survey in Bangladesh [117] and as reviewed by Chakraborti et al. [122] reported that in Ganga-Meghna-Brahmaputra plain, the proportion of As contamination in tube wells is in the range of $20 \%$ to $>50 \%$ and, hence, it is often possible to get uncontaminated tube wells in many areas within reasonable distances and well switching to an uncontaminated shallow tube well can be a suitable option. Among the various tried mitigation strategies, well switching to shallow tube wells has been found as most preferred strategy (29\%) [123]. The major drawback to well switching option is the degree of the spatial and temporal variation in As level in groundwater, making it difficult, unpredictable for its reliably. Further studies reveal that the As concentration in the tube wells changes over time, and it is high during the monsoon period as compared to dry winter season $[124,125]$. This means that the monitoring of each and every well may be required and, furthermore, longterm analysis is equally needed to guarantee that the tube wells will remain As free.

The other factors making this option unconvincing could be socioeconomic barriers, because well switching results in potential usage of other tube wells where entry may be restricted or barred in case of well being privately owned.

5.1.3. Dug Well Water. By constructing open wells, generally called dug wells (DWs) with large diameters, As free safe drinking water can be obtained from As contaminated shallow aquifers. DWs used to be one of the alternative sources of water supply in the Bengal delta, before the installation of tube wells [126]. Studies have shown that the As level in most of the DWs is very low [126-128] due to prevailing oxidative environment and precipitation of $\mathrm{Fe}$ or due to groundwater recharge of the DWs with rainwater with few exceptions [129]. DWs have been suggested as the preferable alternatives of safe drinking water by The National Policy for As Mitigation in areas marked with high concentration of As in Bangladesh [130]. The evaluation of dug well performance in early stages of implementation establishes that these options are appropriate $[131,132]$, although prolonged studies report that tube wells will be the preferred choice over DWs $[133,134]$.

The reasons for the unpopularity of the DWs are obnoxious smell and taste, turbidity, and distance and time bound limitations to fetch water [131, 133]. Bacteriological contamination is the principal problem associated with the use of DWs water. The use of drinking water from these sources without appropriate treatment may lead to diseases like diarrhea, dysentery, typhoid, cholera, and hepatitis. The frequency of microbial contamination of DWs with thermotolerant coliforms (TTC) has been found as high as $94 \%$ with seasonal variation with higher contamination during the monsoon compared to the dry season [135]. New DWs usually have high bacterial contamination, which can be regulated by initial or even repeated disinfection like chlorination [129].

(1) Surface Water. Ponds, lakes, and rivers are generally low or free of As and can be reintroduced in affected areas as a source of safe drinking water. Most of the As affected areas are in the vicinity of a large river and these rivers can serve as sustainable mitigation option for long 
run, that is, over decades. Similar to the DWs, the major and critical limitation of using ponds and lakes is the risk of potential bacteriological contamination which was also the main reason behind replacement of surface water with groundwater as the drinking water source. Reintroduction of surface water as a source of safe drinking water would require antimicrobial treatment like incorporation disinfectants, use of pond sand filters (PSF) [136], or combined surface water treatment units. The use of PSF is preferred by The National Policy for As Mitigation for its application in As-affected regions in Bangladesh [130]. About 95\% PSFs have been found microbially contaminated with elevated levels of TTC in the monsoon season as compared to the dry season [135].

(2) Rainwater Harvesting. Since ancient times, the rainwater harvesting $(\mathrm{RWH})$ has been widely used practice throughout the world as a potential method of utilizing rainwater for domestic water supply [9]. RWH is widely used method at household level globally and there is also an increasing trend on its application at larger community level. The rainwater is safe if it is hygienically maintained and this technology is feasible in areas with average rainfall of $1600 \mathrm{~mm}$ /year or more [137]. RWH is among one of the preferred choices by The National Policy for As Mitigation for use in As-affected areas in Bangladesh [130]. In coastal areas, rainwater is the main source of drinking water because of the high salinity in shallow and deep tube wells. In these areas, rainwater is preserved in large ponds, [138] and the experience from such areas can be transferred to other As affected areas. One of the critical limitations of grass root implementation of rain water harvesting technology is its high installation cost in the form of special roofs and large storage tanks for collection and storage of rain water [126] due to the unequal distribution of rainwater over the year. Microbial contamination is also another limitation $[138,139]$ which can be avoided by discarding the rainwater collected from first flush [9]. Immense care should also be taken on the materials that come in contact with rainwater (especially zinc and lead), as rainwater is slightly acidic and can result in dissolution of metals and other impurities from materials of the catchment and storage tank, leading to unacceptably high concentrations of contaminants in the water $[9,135]$.

5.2. Removal of Arsenic. Removal of As mainly depends on the composition and chemistry of the As contaminated water. As occurs as $\mathrm{As}^{\mathrm{III}}$ in most of the major reported cases and oxidation of $\mathrm{As}^{\mathrm{III}}$ to $\mathrm{As}^{\mathrm{V}}$ is considered as necessary to obtain satisfactory As removals.

5.2.1. Oxidation. The main aim of oxidation is to convert soluble $\mathrm{As}^{\mathrm{II}}$ to $\mathrm{As}{ }^{\mathrm{V}}$, which is followed by precipitation of $\mathrm{As}^{\mathrm{V}}$. This is essential for anoxic groundwater, since As ${ }^{\mathrm{III}}$ is the prevailing form at near neutral $\mathrm{pH}[140]$. $\mathrm{As}^{\mathrm{V}}$ adsorbs more freely onto solid surfaces than $\mathrm{As}^{\mathrm{III}}$ and, thus, oxidation followed by adsorption is deemed to be effective for the removal of As [141, 142]. Several oxidants have been utilized for the oxidation. The kinetics of the reaction with $\mathrm{O}_{3}, \mathrm{H}_{2} \mathrm{O}_{2}, \mathrm{Cl}_{2}, \mathrm{NH}_{2} \mathrm{Cl}$, and ferrate are of first order reactions with reference to both
$\mathrm{As}^{\mathrm{III}}$ and oxidants and, thus, the concentrations of $\mathrm{As}{ }^{\mathrm{III}}$ and the oxidant are the critical parameters for effective removal of As from aqueous solution. The reaction is very fast for permanganate, chlorine, and ozone as compared to hydrogen peroxide and chloramine when applied for oxidation of $\mathrm{As}{ }^{\mathrm{III}}$ to $\mathrm{As}^{\mathrm{V}}$ [142-144]. Bajpai and Chaudhuri [145] reported that $54-57 \%$ of $\mathrm{As}^{\mathrm{III}}$ can be oxidized to $\mathrm{As}^{\mathrm{V}}$ in contaminated groundwater using air and pure oxygen whereas complete oxidation of $\mathrm{As}^{\mathrm{III}}$ can be obtained with ozone. Manganese dioxide polished sand is another oxidant, with the advantage of being both an oxidizing agent as well as an adsorbent. The application of manganese dioxide polished sand is more effective when it is coupled with Fe containing compounds as the treated products are more filterable and easy to handle [145]. Recently, Criscuoli et al. [146] studied the oxidation of $\mathrm{As}^{\text {III }}$ by $\mathrm{MnO}_{2}$ coated PEEC-WC nanostructured capsules and demonstrated that they possess a higher efficiency than conventional oxidation methods when the water contains a low level of As. More than 99\% oxidation was obtained at 100 to $300 \mathrm{ppb}$ of initial As concentration. However, increasing the concentration to 700 and $1000 \mathrm{ppb}$, only $90 \%$ and $73 \%$ of $\mathrm{As}^{\mathrm{III}}$ were oxidized, indicating a decreased oxidation efficiency of the particle with increase in the initial $\mathrm{As}^{\mathrm{III}}$ concentration.

Photochemical and photocatalytic oxidation of As ${ }^{\mathrm{III}}$ has also been explored in several investigations. In water, the rate of oxidation of As ${ }^{\text {III }}$ can be increased by UV radiation in the presence of oxygen. UV/solar light facilitates the generation of hydroxyl radicals through the photolysis of $\mathrm{Fe}(\mathrm{III})$ species $\left(\mathrm{FeOH}_{2}{ }^{+}\right)$and in presence of both hydroxyl radicals and $\mathrm{O}_{2}$, the rate of oxidation becomes faster $[147,148]$. In addition, oxidation of $\mathrm{As}^{\mathrm{III}}$ to $\mathrm{As} \mathrm{v}^{\mathrm{V}}$ by photocatalytic oxidation and $\mathrm{TiO}_{2}$ followed by adsorption of As on $\mathrm{TiO}_{2}$ has also been investigated $[149,150]$.

A $\mathrm{TiO}_{2}$ coated chitosan bead (TICB) was synthesized by Miller and Zimmerman [151] and was applied for oxidation as well as removal of As from aqueous solution. They observed a higher amount of adsorption of As $\left(6400 \mu \mathrm{g} \mathrm{As} \mathrm{s}^{\mathrm{III}} \mathrm{g}^{-1}\right.$ TICB and $\left.4925 \mu \mathrm{g} \mathrm{As}(\mathrm{V}) \mathrm{g}^{-1}\right)$ followed by UV radiation as compared to the solution that was not exposed to UV light $\left(2198 \mu \mathrm{g}\right.$ As (III) ${ }^{-1}$ TICB and $\left.2050 \mu \mathrm{g} \mathrm{As}(\mathrm{V}) \mathrm{gl}^{-1}\right)$. Their study concluded that the surface area of the TICB was increased and $\mathrm{TiO}_{2}$ was able to photooxidize As ${ }^{\mathrm{III}}$ to $\mathrm{As}^{\mathrm{V}}$ in presence of the UV light. In another investigation, [152] synthesized nanocrystal line $\mathrm{Al}_{2} \mathrm{O}_{3}$ and $\mathrm{TiO}_{2}$ impregnated chitosan for the removal of As. The study suggested a mechanism wherein $\mathrm{As}^{\mathrm{III}}$ is photooxidized to $\mathrm{As}^{\mathrm{V}}$ by $\mathrm{TiO}_{2}$ and is subsequently adsorbed by $\mathrm{Al}_{2} \mathrm{O}_{3}$. However, further research is required to implement this system at grass root level. Furthermore, the initial As concentration, $\mathrm{pH}$, natural organic matter (NOM), and the presence of anions essentially affected the rate of adsorption of $\mathrm{As}(\mathrm{V})$ on $\mathrm{TiO}_{2}[150,153-$ 155]. The $\mathrm{TiO}_{2} / \mathrm{UV}$ system has an inefficient removal of As because of incomplete oxidation of $\mathrm{As}^{\mathrm{III}}$ to $\mathrm{As}^{\mathrm{V}}$ when a trace of $\mathrm{TiO}_{2}$ is present [156]. Presence of interfering substances such as $\mathrm{Fe}(\mathrm{II}), \mathrm{Mn}(\mathrm{II})$, sulfide $\left(\mathrm{HS}^{-}\right.$and $\mathrm{S}^{2-}$ ), total 
organic carbon (TOC), and dissolved organic carbon affect the oxidation of $\mathrm{As}^{\mathrm{III}}$ in water samples. In the presence of $\mathrm{S}^{2-}$ and TOC, the oxidation rate of $\mathrm{As}{ }^{\mathrm{III}}$ by ozone severely declines [144].

5.2.2. Coagulation-Flocculation. The incorporation of a coagulant followed by the formation of a floc is a potential method used to remove As from groundwater. Positively charged cationic coagulants decrease the negative charge of the colloids and, consequently, larger particles are formed due to aggregation of particles [157]. The flocs formed in flocculation process are because of polymeric bridging between the flocculent particles which later agglomerate to form larger mass particle. Soluble As is precipitated/coprecipitated onto the flocs and thus eliminated from aqueous solution. For As removal, Fe and Al based coagulants are widely used [158] among the various chemical coagulants. Pallier et al. [159] used kaolinite and $\mathrm{FeCl}_{3}$ as a coagulant/flocculent and they obtained more than $90 \%$ and $77 \%$ removal of $\mathrm{As}^{\mathrm{V}}$ and $\mathrm{As}{ }^{\mathrm{III}}$, respectively, using 9.2 ppm of $\mathrm{Fe}^{3+}$. Recently, $\mathrm{Hu}$ et al. [160] used three aluminum based coagulants (aluminum chloride and two types of poly aluminium chloride) and all of them were found to reduce the concentration of As below the MCL with an initial $\mathrm{As}^{\mathrm{V}}$ concentration of $280 \mathrm{ppb}$. Their study asserted that the aluminum species regulate the removal of As and thus As removal efficiency can be improved by adjusting the $\mathrm{pH}$. Bilici Baskan and Pala [161] optimized the effects of major operational parameters such as the initial As $\mathrm{V}$ concentration, the coagulant dose, and $\mathrm{pH}$ and achieved $91 \%$ removal of $\mathrm{As}^{\mathrm{V}}$ with an initial $\mathrm{As}^{\mathrm{V}}$ concentration of $10 \mathrm{ppb}$ and an $\mathrm{Al}_{2}\left(\mathrm{SO}_{4}\right)_{3}$ coagulant concentration of $66 \mathrm{ppb}$, and a removal of nearly $100 \%$ with an initial $\mathrm{As}^{\mathrm{V}}$ concentration of $500-1000 \mathrm{ppb}$ and a coagulant concentration of 42-56 ppb. Fe based coagulants have also been investigated by several authors [162-165]. Among the chemical coagulants, Fe based coagulants have been found to be efficient in treatment of water than the Al based coagulants [7]. For efficient removal, the As requires to be adsorbed on the amorphous metal hydroxides formed from the coagulant. However, the critical limitation of the coagulation/flocculation process is the production of a huge amount of sludge with a considerable concentration of As. The management of the contaminated sludge is important for safeguarding the environment from secondary pollution and thus reduces the applicability of this method in field conditions.

5.2.3. Adsorption. Removal of As by adsorption onto activated/coated surfaces is getting popular because of its simpler operation and sludge free day to day operation. Several of the adsorbents can be regenerated and reused which is an extra advantage of this technology. Mohan and Pittman [166] reviewed more than 40 different types of adsorbents with more than 500 literature references. In addition, there is an increasing interest in exploration and improvement in new adsorbents. However, excluding few adsorbents like activated alumina and granulated ferric hydroxide, the information about most of the adsorbents is restricted to laboratory evaluations. The removal of As by adsorption techniques in general depends on $\mathrm{pH}$ and the speciation of As with better $\mathrm{As}^{\mathrm{V}}$ removals as compared to $\mathrm{As}{ }^{\mathrm{III}}$ at $\mathrm{pH}$ lower than 7 [167171]. Lin and $\mathrm{Wu}$ [172] reviewed that the rate of As adsorption and capacity adsorbents further depends on presence of other ions like phosphate, silicate, $\mathrm{HCO}^{-3}$, and $\mathrm{Ca}^{2+}$ competing for the adsorption sites. Zhu et al. [170] and Kanematsu et al. [171] also substantiated this fact. The most widely tested aluminium oxide is activated alumina (AA) [172-174] and is prepared by thermal dehydration of aluminium hydroxide. Various pretreatments like impregnation with $\mathrm{Fe}[173,175]$, alum [176], manganese acetate [177], and posthydrolysis [177] have also been explored at lab scale to improve the adsorption efficiency of AA with promising results. Field experience is well documented from various studies, for example, Bamwsp et al. $[178,179]$. Ferrihydrite, granular ferric hydroxide, and hydrous ferric oxide are the most widely explored iron oxides and hydroxides for the removal of As yielding promising results for both $A s^{\mathrm{III}}$ and $\mathrm{As}{ }^{\mathrm{V}}$ removals [174, 180-184]. One of the major problems encountered on the field by aforesaid adsorption methods is the presence of high iron content in groundwater, which emanates into clogging of the filter material thereby reducing the lifetime of the filter [178, 185]. In the last decade, removal of As using zero valent iron (ZVI) or $\mathrm{Fe}(0)$ for removal of As has been widely explored by several research groups both in the laboratory $[142,186$, 187] and in the field [188-192]. The removal mechanisms for As and other contaminants using ZVI have been reviewed by Noubactep in great detail [193]. According to Hussam and Munir [190], approximately 350,000 ZVI filters are operational in Bangladesh, Nepal, Pakistan, India, and Egypt and there are several studies showing promising results of As removals in field [188-192]. However, filters should be maintained properly; otherwise, they are clogged and not reliable in removing As [134].

latest advancements on arsenic removal by sorption.

5.2.4. Latest Advancements on Arsenic Removal by Adsorption. A wide spectrum of different materials have been explored for adsorption of arsenic from groundwater water but iron oxides and oxyhydroxides are the most widely studied and their commercial products already dominate a major portion of the market $[166,194]$. In water treatment plants, iron oxyhydroxides are used as mechanically resistant particles in fixedbed pressure columns. The application of iron oxyhydroxides is encouraged due to their cheap and easy production. The amorphous structure of such hydroxides provides high specific surface area values and their strong affinity and relative high selectivity for the most frequently occurring arsenate species under natural $\mathrm{pH}$-values of potable water.

Tresintsi et al., 2012 [194], synthesized various iron oxyhydroxides between the $\mathrm{pH}$ range 3-12 using the most common low cost iron salts $\left(\mathrm{FeSO}_{4} \cdot \mathrm{H}_{2} \mathrm{O}\right.$ and $\left.\mathrm{FeCl}_{2} \cdot \mathrm{H}_{2} \mathrm{O}\right)$ in a continuous flow kilogram-scale production reactor under intense oxidative conditions to serve as arsenic adsorbents. Synthesized iron oxyhydroxides at acidic ( $\mathrm{pH} 4.0)$ and highly oxidizing conditions resulted in a very effective arsenic adsorbent comprising of uncrystallized schwertmannite. The high $\mathrm{As}^{\mathrm{V}}$ sorption capacity of hydroxides was mainly determined 
by the reaction parameters controlling the effective surface charge and the positive role of adsorbed sulfates in the ion exchange with arsenate oxyanions.

The optimized adsorbent demonstrates the highest reported adsorption capacity while keeping the residual arsenic level below $10 \mathrm{mg} / \mathrm{L}$ (Q10-value) and maintaining its superiority in column investigations as compared to commercial granular materials. This method is simple and economically viable synthetic method adapted in a continuous flow production and a promising technology for scaling up.

Zhang and Sun, 2013 [195], invented multifunctional micro/nanostructured $\mathrm{MnO}_{2}$ spheres successfully and applied them in the removal process of As species from groundwater. Batch experiments revealed that As ${ }^{\mathrm{III}}$ species can be effectively oxidized by the synthesized $\mathrm{MnO}_{2}$ followed by the adsorption of $\mathrm{As}^{\mathrm{V}}$ species. Experimental results of this study insinuated that the synthesized material is repudiated with good adsorption and oxidative capacity required for the removal of arsenic species under controlled conditions. In addition, the synthesized $\mathrm{MnO}_{2}$ spheres can be efficiently recovered for their reuse by a microfiltration process with limited membrane pore blocking owing to the microstructure of the material. Synthesized $\mathrm{MnO}_{2}$ spheres are multifunctional materials with good oxidation, adsorption, and separation properties and can be utilized for water purification.

Cui et al., 2013 [196], synthesized highly porous, nanostructured $\mathrm{ZrO}_{2}$ spheres from amorphous $\mathrm{ZrO}_{2}$ nanoparticles with the help of a food-safe additive, agar powder, which yielded a simple, cheaper, and safer process for the synthesis of $\mathrm{ZrO}_{2}$ spheres. These $\mathrm{ZrO}_{2}$ spheres displayed good adsorption capacity on both $\mathrm{As}^{\mathrm{III}}$ and $\mathrm{As}^{\mathrm{V}}$ at near neutral $\mathrm{pH}$, without the requirement of preoxidation and/or $\mathrm{pH}$ adjustment of the arsenic contaminated water. These $\mathrm{ZrO}_{2}$ spheres are highly stable, nontoxic, acid-alkali resistant and with high arsenic adsorption capacity. These $\mathrm{ZrO}_{2}$ nanoparticles seem to be prospecting material for their promising application in removal of arsenic from groundwater.

Cui, 2014, [197] conducted batch and continuous-flow pilot investigations employing ultrasound (US), ultraviolet (UV), and a combination of US and UV to gauze the rate of oxidation of arsenite $\left(\mathrm{As}^{\mathrm{III}}\right)$. As compared to the single processes of US or UV, the combined US/UV system proved to be the best for As ${ }^{\text {III }}$ oxidation with a synergy index of more than 1.5. A high rate constant of As ${ }^{\mathrm{III}}$ removal was achieved as ferrous [Fe(II)] ions existed. As an energyutilizing oxidation technique does not require a catalyst, the combined energy system employing US/UV followed by MF could be a promising alternative for treating $\mathrm{As}^{\mathrm{III}}$ and $\mathrm{Fe}$ (II) simultaneously.

5.2.5. Biological Arsenic Removal: Basic Techniques. Bacteria play crucial role in geochemical cycling of As by oxidation/reduction reactions, determining its speciation and mobility [1]. Arsenic pentavalent $\left(\mathrm{As}^{\mathrm{V}}\right)$ reduction and arsenic trivalent $\left(\mathrm{As}^{\mathrm{III}}\right)$ oxidation are both detoxification mechanisms [198]. Bacterial species coupling anaerobic oxidation of organic substrates to the reduction of arsenates have also been reported by several researches. Such bacteria are known as dissimilatory arsenate reducing bacteria or arsenate respiring bacteria (ARD), for example, Geospirillum arsenophilus, Geospirillum barnesi, Desulfutomaculum auripigmentum, Bacillus arsenicoselenatis, and Crysiogenes arsenatis [199-202]. These bacteria use $\mathrm{As}^{\mathrm{V}}$ as a terminal electron acceptor in their respiratory process. The oxidation of $\mathrm{As}^{\mathrm{III}}$ is generally carried out by the incorporation of chemical reagents such as ozone, hydrogen peroxide, chlorine, or potassium permanganate [203-205]. The use of chemical reagents in drinking water treatment is discouraged as it often leads to the formation of undesirable byproducts such as trihalomethanes (THMs) [206, 207].

Biological oxidation of $\mathrm{As}^{\mathrm{III}}$ can be applied as an alternative to the chemical oxidation. Iron and manganese are typical unwanted constituents in drinking water causing aesthetic problems known to play significant role in arsenic concentrations in groundwater. Several species of bacteria have been reported to carry out biological oxidation of As [35, 208, 209]. Specific indigenous bacteria mediating biological oxidation of arsenic are known as "iron and manganeseoxidizing bacteria." These bacteria have been successfully applied for the biological arsenic oxidation directly in continuous groundwater treatment [210-212].

The biological oxidation of iron by two bacteria, Gallionella ferruginea and Leptothrix ochracea, has been found to be a promising technology for effective removal of arsenic from groundwater [213]. In this process, iron oxides are coated on filter medium, along with the microorganisms, which offer an ideal environment for arsenic to be adsorbed and removed from the water. Under optimum experimental conditions, trivalent arsenic has been found to be oxidized by these bacteria, contributing to almost complete arsenic removal (up to $95 \%$ ) even when initial arsenic concentrations were $200 \mathrm{mg} / \mathrm{L}$ [213]. The pentavalent arsenic content, under the aforesaid experimental conditions, can be removed significantly, leading to residual concentrations below the newly enforced limit of $10 \mathrm{mg} / \mathrm{L}$. This technology efficiently removes arsenic from groundwater and offers several advantages as compared to conventional physicochemical treatment processes. It avoids the incorporation of chemical reagents for the oxidation of trivalent arsenic; therefore, it is a cost effective and eco-friendly option. In addition, it does not need monitoring of a breakthrough point, as in various sorption processes, because the sorbents (iron oxides) are consistently produced in situ. Due to being a combined treatment process (biological oxidation, filtration, sorption process), it can be used for the simultaneous removal of other inorganic contaminants such as iron, manganese, and arsenic from groundwater [213].

Katsoyiannis et al., 2008, [214] demonstrated the application of a treatment method for the removal of iron, ammonium, manganese, and phosphate from groundwater. In this method, the biological oxidation of ammonium and $\mathrm{Mn}$ (II) for the simultaneous $\mathrm{As}^{\mathrm{III}}$ oxidation and subsequent $\mathrm{As}^{\mathrm{V}}$ removal by coagulation from groundwater was applied. This method is a combined groundwater treatment approach, that 
is, bioremediation coupled with physicochemical treatment with low operational costs [214]. A water treatment unit based on this technology is operational in northern Greece in the city of Malgara. The same can be effectively applied at grass root level in other arsenic contaminated parts of the world.

Katsoyiannis et al. 2013 [215] studied removal of As ${ }^{\text {II }}$ and $\mathrm{As}^{\mathrm{V}}$ from groundwater by the application of biological oxidation of dissolved iron and manganese in a pipe reactor (PR), followed by microfiltration (MF). The groundwater under test (Berlin, Marienfelde) contained average $\mathrm{Fe}(\mathrm{U})$ and $\mathrm{Mn}(\mathrm{II})$ concentrations of 2.9 and $0.6 \mathrm{mg} / \mathrm{L}$, respectively. Oxidation of these metals imparted adequate adsorption sites and, therefore, arsenic species could be removed from groundwater effectively. The residual concentrations in all cases were found to be reduced up to $10 \mu \mathrm{g} / \mathrm{L}$. The initial concentration of arsenic in water was in the range of 20 to $250 \mu \mathrm{g} / \mathrm{L}$.

Advantageous aspect of this technology is the uptake of oxidized iron and manganese onto recirculated suspended solids which flocculated in the pipe reactor, thereby eliminating the requirement for mechanical cleaning of the membrane, while keeping the transmembrane pressure (TMP) constantly low. The $\mathrm{As}^{\mathrm{V}}$ removal capacity of this hybrid PR-MF unit was found to be significantly higher than that achieved by conventional coagulation-filtration with $\mathrm{Fe}$ (III). Conclusively, the very latest PR-MF process efficiently removes iron, manganese, and arsenic without using chemical reagents for oxidation or $\mathrm{pH}$ adjustment, and without the requirement of regular regeneration or backwashing, and thus it follows the principles of green chemistry [215].

\section{Conclusion}

Arsenic contamination of groundwater is an alarming problem on a global scale. In several parts of the world, biogeochemical processes have resulted in dissolution of naturally occurring As into groundwater. In present review, we tried to elaborate on different natural and anthropogenic sources of As in groundwater including its speciation and mobilization pattern in groundwater. We have also reviewed problem of As contamination in groundwater in different parts of the world followed by detailed outlook in epidemiology and toxicity mechanisms of As in animals and humans. In order to combat arsenic problem, various remediation methods based on conventional, modern, and hybrid technologies for removal of As in several parts of the world have been critically reviewed. The merits and demerits of these technologies have been discussed in detail. Most of the existing technologies for removal of As involve the direct removal of $\mathrm{As}^{\mathrm{V}}$ or converting $A s^{\mathrm{III}}$ to $\mathrm{As}^{\mathrm{V}}$ followed by removal of $\mathrm{As}^{\mathrm{V}}$. The implementation of mitigation options can be facilitated by setting proper guidelines and to control implementation at appropriate intervals. The awareness of the population is deemed equally important in maintaining and choosing mitigation. However, even for well-aware population, the dilemma is often the ability to meet prohibitive costs versus the wish to improve their situation. For communities public participation encounters the same constraints. Governmental and donor financial and logistic assistance may be essential to reduce arsenicosis. Besides, extensive research should address the understanding of the occurrence, origin, and distribution pattern of arsenic. The government should monitor industrial and agricultural activities leading to As pollution. More technical assistance should be rendered to mining or chemical plants to deal with sewage and sludge storage and waste treatment. Supervision departments should increase the frequency of sampling and analysis of the discharge from industrial plants. We sincerely hope that this paper will be of considerable interest to the readers. The paper reflects the latest state of the art on understanding of various interdisciplinary facets of the problem of arsenic in environmental realm, mechanisms of mobilization in groundwater, biogeochemical interactions, and the measure for remediation.

\section{Abbreviations}

\begin{tabular}{|c|c|}
\hline As: & Arsenic \\
\hline As ${ }^{\mathrm{III}}:$ & Arsenite \\
\hline $\mathrm{As}^{\mathrm{V}}:$ & Arsenate \\
\hline $\mathrm{MMA}^{\mathrm{V}}:$ & Monomethylarsonic \\
\hline $\mathrm{DMA}^{\mathrm{V}}:$ & Dimethylarsinic \\
\hline MMA $^{\mathrm{III}}$ : & Monomethylarsonous \\
\hline $\mathrm{DMA}^{\mathrm{III}}:$ & Dimethylarsinous \\
\hline AS3MT: & Arsenite methyltransferase \\
\hline SAM: & S-Adenosylmethionine \\
\hline $\mathrm{As}(\mathrm{GS})_{2}-\mathrm{OH}, \mathrm{As}(\mathrm{GS})_{3}:$ & Arsenite-glutathione complex \\
\hline GSH: & Glutathione \\
\hline ROS: & Reactive oxygen species \\
\hline DRAM: & $\begin{array}{l}\text { Damage-regulated autophagy } \\
\text { modulator }\end{array}$ \\
\hline ppb: & Parts per billion \\
\hline ppm: & Parts per million, \\
\hline DMA(GS): & Dimethylarsinic glutathione \\
\hline DWs: & Dug wells \\
\hline MCL: & Maximum contaminant level \\
\hline ERCC1: & $\begin{array}{l}\text { Excision repair } \\
\text { cross-complement. }\end{array}$ \\
\hline
\end{tabular}

\section{Conflict of Interests}

The authors declare that there is no conflict of interests regarding the publication of this paper.

\section{Acknowledgment}

One of the authors, Dr. Uma Shanker, is thankful to the Director of Dr. B. R. Ambedkar National Institute of Technology Jalandhar, Punjab, India.

\section{References}

[1] P. L. Smedley and D. G. Kinniburgh, "A review of the source, behaviour and distribution of arsenic in natural waters," Applied Geochemistry, vol. 17, no. 5, pp. 517-568, 2002. 
[2] P. Bhattacharya, G. Jacks, K. M. Ahmed, J. Routh, and A. A. Khan, "Arsenic in groundwater of the Bengal Delta Plain aquifers in Bangladesh," Bulletin of Environmental Contamination and Toxicology, vol. 69, no. 4, pp. 538-545, 2002.

[3] P. Bhattacharya, D. Chatterjee, and G. Jacks, "Occurrence of arsenic-contaminated groundwater in alluvial aquifers from delta plains, eastern India: options for safe drinking water supply," International Journal of Water Resources Development, vol. 13, no. 1, pp. 79-92, 1997.

[4] P. Bhattacharya, A. H. Welch, K. G. Stollenwerk, M. J. McLaughlin, J. Bundschuh, and G. Panaullah, "Arsenic in the environment: biology and chemistry," Science of the Total Environment, vol. 379, no. 2-3, pp. 109-120, 2007.

[5] J. Bundschuh, M. E. Garcia, P. Birke, L. H. Cumbal, P. Bhattacharya, and J. Matschullat, "Occurrence, health effects and remediation of arsenic in groundwaters of Latin America," in Natural Arsenic in Groundwaters of Latin America, J. Bhattacharya, A. B. Matschullat, M. A. Armientan et al., Eds., pp. 3-15, Taylor \& Francis, London, UK, 2009.

[6] P. Bhattacharya, M. Hossain, S. N. Rahman et al., "Temporal and seasonal variability of arsenic in drinking water wells in Matlab, southeastern Bangladesh: a preliminary evaluation on the basis of a 4 year study," Journal of Environmental Science and Health A: Toxic/Hazardous Substances and Environmental Engineering, vol. 46, no. 11, pp. 1177-1184, 2011.

[7] P. Ravenscroft, H. Brammer, and K. Richards, Arsenic Pollution: A Global Synthesis, John Wiley \& Sons, West Sussex, UK, 2009.

[8] USEPA, "National Primary Drinking Water Regulations: Arsenic and Clarifications to Compliance and New Source Contaminants Monitoring," Federal Register, vol. 40, CFR Parts 9, pp. 141-142, 2001.

[9] WHO, Guidelines for Drinking-Water Quality, vol. 4, World Health Organization, 2011.

[10] USEPA, "Arsenic in Drinking Water," 2013, http://water.epa.gov/ lawsregs/rulesregs/sdwa/arsenic/index.cfm.

[11] S. C. Santra, A. C. Samal, P. Bhattacharya, S. Banerjee, A. Biswas, and J. Majumdar, "Arsenic in foodchain and community health risk: a study in gangetic west Bengal," Procedia Environmental Sciences, vol. 18, pp. 2-13, 2013, Proceedings of the International Symposium on Environmental Science and Technology (2013 ISEST).

[12] A. Rai, P. Tripathi, S. Dwivedi et al., "Arsenic tolerances in rice (Oryza sativa) have a predominant role in transcriptional regulation of a set of genes including sulphur assimilation pathway and antioxidant system," Chemosphere, vol. 82, no. 7, pp. 986-995, 2011.

[13] J. Brinkel, M. H. Khan, and A. Kraemer, "A systematic review of arsenic exposure and its social and mental health effects with special reference to Bangladesh," International Journal of Environmental Research and Public Health, vol. 6, no. 5, pp. 1609-1619, 2009.

[14] J. L. Stroud, G. J. Norton, M. R. Islam et al., "The dynamics of arsenic in four paddy fields in the Bengal delta," Environmental Pollution, vol. 159, no. 4, pp. 947-953, 2011.

[15] S. Fendorf, H. A. Michael, and A. van Geen, "Spatial and temporal variations of groundwater arsenic in South and Southeast Asia," Science, vol. 328, no. 5982, pp. 1123-1127, 2010.

[16] N. Mirlean, P. Baisch, and D. Diniz, "Arsenic in groundwater of the Paraiba do Sul delta, Brazil: an atmospheric source?" Science of the Total Environment, vol. 482-483, pp. 148-156, 2014.

[17] A. Mukherjee, M. K. Sengupta, M. A. Hossain et al., "Arsenic contamination in groundwater: a global perspective with emphasis on the Asian scenario," Journal of Health, Population and Nutrition, vol. 24, no. 2, pp. 142-163, 2006.

[18] D. Chakraborti, M. M. Rahman, B. Das et al., "Status of groundwater arsenic contamination in Bangladesh: a 14-year study report," Water Research, vol. 44, no. 19, pp. 5789-5802, 2010.

[19] D. P. Shukla, C. S. Dubey, N. P. Singh, M. Tajbakhsh, and M. Chaudhry, "Sources and controls of Arsenic contamination in groundwater of Rajnandgaon and Kanker District, Chattisgarh Central India," Journal of Hydrology, vol. 395, no. 1-2, pp. 49-66, 2010.

[20] S. Sthiannopkao, K. W. Kim, S. Sotham, and S. Choup, "Arsenic and manganese in tube well waters of Prey Veng and Kandal Provinces, Cambodia," Applied Geochemistry, vol. 23, no. 5, pp. 1086-1093, 2008.

[21] J. Nriagu, P. Bhattacharya, A. Mukherjee, J. Bundschuh, R. Zevenhoven, and R. Loeppert, "Arsenic in soil and groundwater: an overview," in Arsenic in Soil and Groundwater Environment, P. Bhattacharya, A. Mukherjee, J. Bundschuh, R. Zevenhoven, and R. Loeppert, Eds., pp. 3-60, Elsevier, Amsterdam, The Netherlands, 2007.

[22] M. A. Khan and Y.-S. Ho, "Arsenic in drinking water: a review on toxicological effects, mechanism of accumulation and remediation," Asian Journal of Chemistry, vol. 23, no. 5, pp. 1889-1901, 2011.

[23] J. J. Gómez, J. Lillo, and B. Sahún, "Naturally occurring arsenic in groundwater and identification of the geochemical sources in the Duero Cenozoic Basin, Spain," Environmental Geology, vol. 50, no. 8, pp. 1151-1170, 2006.

[24] W. G. Cutler, R. C. Brewer, A. El-Kadi et al., "Bioaccessible arsenic in soils of former sugar cane plantations, Island of Hawaii," Science of the Total Environment, vol. 442, pp. 177-188, 2013.

[25] R. Tuli, D. Chakrabarty, P. K. Trivedi, and R. D. Tripathi, "Recent advances in arsenic accumulation and metabolism in rice," Molecular Breeding, vol. 26, no. 2, pp. 307-323, 2010.

[26] Y. Chen, F. Parvez, M. Gamble et al., "Arsenic exposure at low-to-moderate levels and skin lesions, arsenic metabolism, neurological functions, and biomarkers for respiratory and cardiovascular diseases: review of recent findings from the Health Effects of Arsenic Longitudinal Study (HEALS) in Bangladesh," Toxicology and Applied Pharmacology, vol. 239, no. 2, pp. 184-192, 2009.

[27] M. Bissen and F. H. Frimmel, "Arsenic: a review-part I-: occurrence, toxicity, speciation, mobility," Acta Hydrochimica et Hydrobiologica, vol. 31, no. 1, pp. 9-18, 2003.

[28] J. Matschullat, "Arsenic in the geosphere-a review," Science of the Total Environment, vol. 249, no. 1-3, pp. 297-312, 2000.

[29] M. L. Polizzotto, C. F. Harvey, G. Li et al., "Solid-phases and desorption processes of arsenic within Bangladesh sediments," Chemical Geology, vol. 228, no. 1-3, pp. 97-111, 2006.

[30] R. P. Borba, B. R. Figueiredo, and J. Matschullat, "Geochemical distribution of arsenic in waters, sediments and weathered gold mineralized rocks from Iron Quadrangle, Brazil," Environmental Geology, vol. 44, no. 1, pp. 39-52, 2003.

[31] L. Charlet, S. Chakraborty, C. A. J. Appelo et al., "Chemodynamics of an arsenic "hotspot" in a West Bengal aquifer: a field and reactive transport modeling study," Applied Geochemistry, vol. 22, no. 7, pp. 1273-1292, 2007.

[32] A. M. Islam, Membrane distillation process for pure water and removal of arsenic [Master of Science thesis for International Master's Program in Applied Environmental Measurement 
Techniques], Chalmers University of Technology, Gothenburg, Sweden, 2004.

[33] S. Bhowmick, B. Nath, D. Halder et al., "Arsenic mobilization in the aquifers of three physiographic settings of West Bengal, India: understanding geogenic and anthropogenic influences," Journal of Hazardous Materials, vol. 262, pp. 915-923, 2013.

[34] J. F. Ferguson and J. Gavis, "A review of the arsenic cycle in natural waters," Water Research, vol. 6, no. 11, pp. 1259-1274, 1972.

[35] W. R. Cullen and K. J. Reimer, "Arsenic speciation in the environment," Chemical Reviews, vol. 89, no. 4, pp. 713-764, 1989.

[36] A. H. Welch, M. S. Lico, and J. L. Hughes, "Arsenic in ground water of the Western United States," Ground Water, vol. 26, no. 3, pp. 333-347, 1988.

[37] A. H. Welch, D. B. Westjohn, D. R. Helsel, and R. B. Wanty, "Arsenic in ground water of the United States: occurrence and geochemistry," Ground Water, vol. 38, no. 4, pp. 589-604, 2000.

[38] W.-M. Mok and C. M. Wai, "Distribution and mobilization of arsenic and antimony species in the Coeur D'Alene River, Idaho," Environmental Science and Technology, vol. 24, no. 1, pp. 102-108, 1990.

[39] L. C. D. Andersen and K. W. Bruland, "Biogeochemistry of arsenic in natural waters: the importance of methylated species," Environmental Science and Technology, vol. 25, no. 3, pp. 420427, 1991.

[40] M.-J. Kim, J. Nriagu, and S. Haack, "Arsenic behavior in newly drilled wells," Chemosphere, vol. 52, no. 3, pp. 623-633, 2003.

[41] S. Haque and K. H. Johannesson, "Arsenic concentrations and speciation along a groundwater flow path: the Carrizo Sand aquifer, Texas, USA," Chemical Geology, vol. 228, no. 1-3, pp. 5771, 2006.

[42] S. E. Haque and K. H. Johannesson, "Concentrations and speciation of arsenic along a groundwater flow-path in the Upper Floridan aquifer, Florida, USA," Environmental Geology, vol. 50, no. 2, pp. 219-228, 2006.

[43] S. Haque, J. Ji, and K. H. Johannesson, "Evaluating mobilization and transport of arsenic in sediments and groundwaters of Aquia aquifer, Maryland, USA," Journal of Contaminant Hydrology, vol. 99, no. 1-4, pp. 68-84, 2008.

[44] C. K. Jain and I. Ali, "Arsenic: occurrence, toxicity and speciation techniques," Water Research, vol. 34, no. 17, pp. 4304-4312, 2000.

[45] J. G. Hering and P. E. Kneebone, "Biogeochemical controls on arsenic occurrence and mobility in water supplies," in Environmental Chemistry of Arsenic, pp. 155-182, Marcel Dekker, New York, NY, USA, 2001.

[46] H. Guo, B. Zhang, Y. Li et al., "Hydrogeological and biogeochemical constrains of arsenic mobilization in shallow aquifers from the Hetao basin, Inner Mongolia," Environmental Pollution, vol. 159, no. 4, pp. 876-883, 2011.

[47] S. Murcott, Arsenic Contamination in the World: An International Sourcebook, IWA Publishing, London, UK, 2012.

[48] J. S. Petrick, F. Ayala-Fierro, W. R. Cullen, D. E. Carter, and H. Vasken Aposhian, "Monomethylarsonous acid (MMA ${ }^{I I I}$ ) is more toxic than arsenite in chang human hepatocytes," Toxicology and Applied Pharmacology, vol. 163, no. 2, pp. 203207, 2000.

[49] J. Gailer, "Arsenic-selenium and mercury-selenium bonds in biology," Coordination Chemistry Reviews, vol. 251, no. 1-2, pp. 234-254, 2007.
[50] Z. Liu, J. Shen, J. M. Carbrey, R. Mukhopadhyay, P. Agre, and B. P. Rosen, "Arsenite transport by mammalian aquaglyceroporins AQP7 and AQP9," Proceedings of the National Academy of Sciences of the United States of America, vol. 99, no. 9, pp. 60536058, 2002.

[51] R. Villa-Bellosta and V. Sorribas, "Role of rat sodium/phosphate cotransporters in the cell membrane transport of arsenate," Toxicology and Applied Pharmacology, vol. 232, no. 1, pp. 125$134,2008$.

[52] R.-N. Huang and T.-C. Lee, "Cellular uptake of trivalent arsenite and pentavalent arsenate in KB cells cultured in phosphate-free medium," Toxicology and Applied Pharmacology, vol. 136, no. 2, pp. 243-249, 1996.

[53] C. Kojima, D. C. Ramirez, E. J. Tokar et al., "Requirement of arsenic biomethylation for oxidative DNA damage," Journal of the National Cancer Institute, vol. 101, no. 24, pp. 1670-1681, 2009.

[54] F. Challenger, "Biological methylation," Chemical Reviews, vol. 36, no. 3, pp. 315-361, 1945.

[55] R. A. Zakharyan and H. V. Aposhian, "Arsenite methylation by methylvitamin B12 and glutathione does not require an enzyme," Toxicology and Applied Pharmacology, vol. 154, no. 3, pp. 287-291, 1999.

[56] T. Hayakawa, Y. Kobayashi, X. Cui, and S. A. Hirano, "A new metabolic pathway of arsenite: Arsenic-glutathione complexes are substrates for human arsenic methyltransferase Cyt19," Archives in Toxicology, vol. 79, no. 4, pp. 183-191, 2005.

[57] K. Rehman and H. Naranmandura, "Arsenic metabolism and thioarsenicals," Metallomics, vol. 4, no. 9, pp. 881-892, 2012.

[58] H. Naranmandura, N. Suzuki, and K. T. Suzuki, "Trivalent arsenicals are bound to proteins during reductive methylation," Chemical Research in Toxicology, vol. 19, no. 8, pp. 1010-1018, 2006.

[59] V. Devesa, L. M. Del Razo, B. Adair et al., "Comprehensive analysis of arsenic metabolites by $\mathrm{pH}$-specific hydride generation atomic absorption spectrometry," Journal of Analytical Atomic Spectrometry, vol. 19, no. 11, pp. 1460-1467, 2004.

[60] S. Tapio and B. Grosche, "Arsenic in the aetiology of cancer," Mutation Research-Genetic Toxicology and Environmental Mutagenesis, vol. 612, pp. 215-246, 2006.

[61] T. Yoshida, H. Yamauchi, and G. Fan Sun, "Chronic health effects in people exposed to arsenic via the drinking water: dose-response relationships in review," Toxicology and Applied Pharmacology, vol. 198, no. 3, pp. 243-252, 2004.

[62] H. Shi, X. Shi, and K. J. Liu, "Oxidative mechanism of arsenic toxicity and carcinogenesis," Molecular and Cellular Biochemistry, vol. 255, no. 1-2, pp. 67-78, 2004.

[63] T.-S. Wang, T.-Y. Hsu, C.-H. Chung, A. S. S. Wang, D.-T. Bau, and K.-Y. Jan, "Arsenite induces oxidative DNA adducts and DNA-protein cross-links in mammalian cells," Free Radical Biology and Medicine, vol. 31, no. 3, pp. 321-330, 2001.

[64] K. T. Suzuki, K. Kurasaki, and N. Suzuki, "Selenocysteine $\beta$ lyase and methylselenol demethylase in the metabolism of Se-methylated selenocompounds into selenide," Biochimica et Biophysica Acta-General Subjects, vol. 1770, no. 7, pp. 10531061, 2007.

[65] T.-C. Zhang, M. T. Schmitt, and J. L. Mumford, "Effects of arsenic on telomerase and telomeres in relation to cell proliferation and apoptosis in human keratinocytes and leukemia cells in vitro," Carcinogenesis, vol. 24, no. 11, pp. 1811-1817, 2003. 
[66] L. Benbrahim-Tallaa, R. A. Waterland, M. Styblo, W. E. Achanzar, M. M. Webber, and M. P. Waalkes, "Molecular events associated with arsenic-induced malignant transformation of human prostatic epithelial cells: aberrant genomic DNA methylation and K-ras oncogene activation," Toxicology and Applied Pharmacology, vol. 206, no. 3, pp. 288-298, 2005.

[67] P. R. Gentry, T. B. McDonald, D. E. Sullivan, A. M. Shipp, J. W. Yager, and H. J. Clewell III, "Analysis of genomic dose-response information on arsenic to inform key events in a mode of action for carcinogenicity," Environmental and Molecular Mutagenesis, vol. 51, no. 1, pp. 1-14, 2010.

[68] A. K. Sharma, J. C. Tjell, and H. Mosbæk, "Health effects from arsenic in groundwater of the Bengal delta: effects of iron and water storage practices," Environmental Geosciences, vol. 13, no. 1, pp. 17-29, 2006.

[69] L. Wang, M.-C. Kou, C.-Y. Weng, L.-W. Hu, Y.-J. Wang, and M.J. Wu, "Arsenic modulates heme oxygenase-1, interleukin-6, and vascular endothelial growth factor expression in endothelial cells: roles of ROS, NF $-\kappa \mathrm{B}$, and MAPK pathways," Archives of Toxicology, vol. 86, no. 6, pp. 879-896, 2012.

[70] D. Sinha, J. Biswas, and A. Bishayee, "Nrf2-mediated redox signaling in arsenic carcinogenesis: a review," Archives of Toxicology, vol. 87, no. 2, pp. 383-396, 2013.

[71] H. Shi, L. G. Hudson, W. Ding et al., "Arsenite causes DNA damage in keratinocytes via generation of hydroxyl radicals," Chemical Research in Toxicology, vol. 17, no. 7, pp. 871-878, 2004.

[72] M. Wei, H. Wanibuchi, K. Morimura et al., "Carcinogenicity of dimethylarsinic acid in male F344 rats and genetic alterations in induced urinary bladder tumors," Carcinogenesis, vol. 23, no. 8, pp. 1387-1397, 2002.

[73] J. A. Centeno, F. G. Mullick, L. Martinez et al., "Pathology related to chronic arsenic exposure," Environmental Health Perspectives, vol. 110, no. 5, pp. 883-886, 2002.

[74] A. K. Sharma, J. C. Tjell, J. J. Sloth, and P. E. Holm, "Review of arsenic contamination, exposure through water and food and low cost mitigation options for rural areas," Applied Geochemistry, vol. 41, pp. 1-33, 2014.

[75] D. S. Paul, A. W. Harmon, V. Devesa, D. J. Thomas, and M. Stýblo, "Molecular mechanisms of the diabetogenic effects of arsenic: inhibition of insulin signaling by arsenite and methylarsonous acid," Environmental Health Perspectives, vol. 115, no. 5, pp. 734-742, 2007.

[76] C. Douillet, J. Currier, J. Saunders, W. M. Bodnar, T. Matoušek, and M. Stýblo, "Methylated trivalent arsenicals are potent inhibitors of glucose stimulated insulin secretion by murine pancreatic islets," Toxicology and Applied Pharmacology, vol. 267, no. 1, pp. 11-15, 2013.

[77] A. Navas-Acien, E. K. Silbergeld, R. A. Streeter, J. M. Clark, T. A. Burke, and E. Guallar, "Arsenic exposure and type 2 diabetes: a systematic review of the experimental and epidemiologic evidence," Environmental Health Perspectives, vol. 114, no. 5, pp. 641-648, 2006.

[78] L. N. Abhyankar, M. R. Jones, E. Guallar, and A. Navas-Acien, "Arsenic exposure and hypertension: a systematic review," Environmental Health Perspectives, vol. 120, no. 4, pp. 494-500, 2012.

[79] B. Halliwell, "Oxidative stress and cancer: have we moved forward?” Biochemical Journal, vol. 401, no. 1, pp. 1-11, 2007.

[80] S. Nesnow, B. C. Roop, G. Lambert et al., "DNA damage induced by methylated trivalent arsenicals is mediated by reactive oxygen species," Chemical Research in Toxicology, vol. 15, no. 12, pp. 1627-1634, 2002.
[81] K. E. Eblin, M. E. Bowen, D. W. Cromey et al., "Arsenite and monomethylarsonous acid generate oxidative stress response in human bladder cell culture," Toxicology and Applied Pharmacology, vol. 217, no. 1, pp. 7-14, 2006.

[82] R. C. McKenzie, J. R. Arthur, and G. J. Beckett, "Selenium and the regulation of cell signaling, growth, and survival: molecular and mechanistic aspects," Antioxidants \& Redox Signaling, vol. 4, no. 2, pp. 339-351, 2002.

[83] V. Selvaraj, J. Tomblin, M. Y. Armistead, and E. Murray, "Selenium (sodium selenite) causes cytotoxicity and apoptotic mediated cell death in PLHC-1 fish cell line through DNA and mitochondrial membrane potential damage," Ecotoxicology and Environmental Safety, vol. 87, pp. 80-88, 2013.

[84] H. Sies and H. de Groot, "Role of reactive oxygen species in cell toxicity," Toxicology Letters, vol. 64-65, pp. 547-551, 1992.

[85] W.-C. Chou, C. Jie, A. A. Kenedy, R. J. Jones, M. A. Trush, and C. V. Dang, "Role of NADPH oxidase in arsenic-induced reactive oxygen species formation and cytotoxicity in myeloid leukemia cells," Proceedings of the National Academy of Sciences of the United States of America, vol. 101, no. 13, pp. 4578-4583, 2004.

[86] T.-S. Kim, D.-W. Jeong, Y. Y. Byung, and Y. K. Ick, "Dysfunction of rat liver mitochondria by selenite: induction of mitochondrial permeability transition through thiol-oxidation," Biochemical and Biophysical Research Communications, vol. 294, no. 5, pp. 1130-1137, 2002.

[87] H. K. Eun, S. Sohn, J. K. Hyuk et al., "Sodium selenite induces superoxide-mediated mitochondrial damage and subsequent autophagic cell death in malignant glioma cells," Cancer Research, vol. 67, no. 13, pp. 6314-6324, 2007.

[88] H.-M. Shen, C.-F. Yang, W.-X. Ding, J. Liu, and C.-N. Ong, "Superoxide radical-initiated apoptotic signalling pathway in selenite-treated HepG2 cells: mitochondria serve as the main target," Free Radical Biology \& Medicine, vol. 30, no. 1, pp. 9-21, 2001.

[89] H.-M. Shen and Z.-G. Liu, "JNK signaling pathway is a key modulator in cell death mediated by reactive oxygen and nitrogen species," Free Radical Biology and Medicine, vol. 40, no. 6, pp. 928-939, 2006.

[90] Y. J. Suzuki, H. J. Forman, and A. Sevanian, "Oxidants as stimulators of signal transduction," Free Radical Biology and Medicine, vol. 22, no. 1-2, pp. 269-285, 1997.

[91] K. Apel and H. Hirt, "Reactive oxygen species: metabolism, oxidative stress, and signal transduction," Annual Review of Plant Biology, vol. 55, pp. 373-399, 2004.

[92] C. Huang, W.-Y. Ma, J. Li, and Z. Dong, "Arsenic induces apoptosis through a c-Jun NH2-terminal kinase- dependent, p53-independent pathway," Cancer Research, vol. 59, no. 13, pp. 3053-3058, 1999.

[93] L.-H. Yih and T.-C. Lee, "Arsenite induces p53 accumulation through an ATM-dependent pathway in human fibroblasts," Cancer Research, vol. 60, no. 22, pp. 6346-6352, 2000.

[94] S. A. Amundson, T. G. Myers, and A. J. Fornace Jr., "Roles for p53 in growth arrest and apoptosis: Putting on the brakes after genotoxic stress," Oncogene, vol. 17, no. 25, pp. 3287-3299, 1998.

[95] K. M. Ryan, A. C. Phillips, and K. H. Vousden, "Regulation and function of the p53 tumor suppressor protein," Current Opinion in Cell Biology, vol. 13, no. 3, pp. 332-337, 2001.

[96] J. Bargonetti and J. J. Manfredi, "Multiple roles of the tumor suppressor p53," Current Opinion in Oncology, vol. 14, no. 1, pp. 86-91, 2002. 
[97] F. Kircelli, C. Akay, and Y. Gazitt, "Arsenic trioxide induces p53-dependent apoptotic signals in myeloma cells with SiRNAsilenced p53: MAP kinase pathway is preferentially activated in cells expressing inactivated p53," International Journal of Oncology, vol. 30, no. 4, pp. 993-1001, 2007.

[98] B. Vogelstein, D. Lane, and A. J. Levine, "Surfing the p53 network," Nature, vol. 408, no. 6810, pp. 307-310, 2000.

[99] C. Akay, C. Thomas III, and Y. Gazitt, "Arsenic trioxide and paclitaxel induce apoptosis by different mechanisms," Cell Cycle, vol. 3, no. 3, pp. 324-334, 2004.

[100] D. Crighton, S. Wilkinson, J. O’Prey et al., "DRAM, a p53induced modulator of autophagy, is critical for apoptosis," Cell, vol. 126, no. 1, pp. 121-134, 2006.

[101] J. Lu, C. Jiang, M. Kaeck et al., "Dissociation of the genotoxic and growth inhibitory effects of selenium," Biochemical Pharmacology, vol. 50, no. 2, pp. 213-219, 1995.

[102] V. Valdiglesias, E. Pásaro, J. Méndez, and B. Laffon, "In vitro evaluation of selenium genotoxic, cytotoxic, and protective effects: a review," Archives of Toxicology, vol. 84, no. 5, pp. 337351, 2010.

[103] T. K. Hei and M. Filipic, "Role of oxidative damage in the genotoxicity of arsenic," Free Radical Biology \& Medicine, vol. 37, no. 5, pp. 574-581, 2004.

[104] C. V. Ramana, I. Boldogh, T. Izumi, and S. Mitra, "Activation of apurinic/apyrimidinic endonuclease in human cells by reactive oxygen species and its correlation with their adaptive response to genotoxicity of free radicals," Proceedings of the National Academy of Sciences of the United States of America, vol. 95, no. 9, pp. 5061-5066, 1998.

[105] A. Hartwig, "Zinc finger proteins as potential targets for toxic metal ions: differential effects on structure and function," Antioxidants and Redox Signaling, vol. 3, no. 4, pp. 625-634, 2001.

[106] X. Zhou, X. Sun, K. L. Cooper, F. Wang, K. J. Liu, and L. G. Hudson, "Arsenite interacts selectively with zinc finger proteins containing $\mathrm{C} 3 \mathrm{H} 1$ or $\mathrm{C} 4$ motifs," The Journal of Biological Chemistry, vol. 286, no. 26, pp. 22855-22863, 2011.

[107] E. Ho, "Zinc deficiency, DNA damage and cancer risk," Journal of Nutritional Biochemistry, vol. 15, no. 10, pp. 572-578, 2004.

[108] A. S. Andrew, M. R. Karagas, and J. W. Hamilton, "Decreased DNA repair gene expression among individuals exposed to arsenic in United States drinking water," International Journal of Cancer, vol. 104, no. 3, pp. 263-268, 2003.

[109] A. S. Andrew, J. L. Burgess, M. M. Meza et al., "Arsenic exposure is associated with decreased DNA repair in vitro and in individuals exposed to drinking water arsenic," Environmental Health Perspectives, vol. 114, no. 8, pp. 1193-1198, 2006.

[110] G. Sciandrello, F. Caradonna, M. Mauro, and G. Barbata, "Arsenic-induced DNA hypomethylation affects chromosomal instability in mammalian cells," Carcinogenesis, vol. 25, no. 3, pp. 413-417, 2004.

[111] C. Q. Zhao, M. R. Young, B. A. Diwan, T. P. Coogan, and M. P. Waalkes, "Association of arsenic-induced malignant transformation with DNA hypomethylation and aberrant gene expression," Proceedings of the National Academy of Sciences of the United States of America, vol. 94, no. 20, pp. 10907-10912, 1997.

[112] M. Stýblo and D. J. Thomas, "In vitro inhibition of glutathione reductase by arsenotriglutathione," Biochemical Pharmacology, vol. 49, no. 7, pp. 971-977, 1995.
[113] S. Lin, W. R. Cullen, and D. J. Thomas, "Methylarsenicals and arsinothiols are potent inhibitors of mouse liver thioredoxin reductase," Chemical Research in Toxicology, vol. 12, no. 10, pp. 924-930, 1999.

[114] C. X. Zhong and M. J. Mass, "Both hypomethylation and hypermethylation of DNA associated with arsenite exposure in cultures of human cells identified by methylation-sensitive arbitrarily-primed PCR," Toxicology Letters, vol. 122, no. 3, pp. 223-234, 2001.

[115] X. H. Jiang, Y. Chun, B. Wong et al., "Arsenic trioxide induces apoptosis in human gastric cancer cells through up-regulation of P53 and activation of caspase-3," International Journal of Cancer, vol. 91, pp. 173-179, 2001.

[116] H. Heijnen, "Criteria for selection of technologies for arsenic mitigation," in Arsenic Contamination: Bangladesh Perspective, pp. 429-441, ITN, Dhaka, Bangladesh, 2003.

[117] BGS, "DPHE/BGS National Hydrochemical Survey," 2004, http://www.bgs.ac.uk/research/groundwater/health/arsenic/ Bangladesh/mapsnhs.html.

[118] DPHE, Proceedings of: Deeper Aquifers of Bangladesh-A Review Meeting, Department of Public Health Engineering with support from UNICEF and the Water \& Sanitation Program.

[119] L. H. E. Winkel, P. T. K. Trang, V. M. Lan et al., "Arsenic pollution of groundwater in Vietnam exacerbated by deep aquifer exploitation for more than a century," Proceedings of the National Academy of Sciences of the United States of America, vol. 108, no. 4, pp. 1246-1251, 2011.

[120] M. A. Hoque and W. G. Burgess, " ${ }^{14} \mathrm{C}$ dating of deep groundwater in the Bengal Aquifer System, Bangladesh: implications for aquifer anisotropy, recharge sources and sustainability," Journal of Hydrology, vol. 444-445, pp. 209-220, 2012.

[121] S. J. Hug, D. Gaertner, L. C. Roberts et al., "Avoiding high concentrations of arsenic, manganese and salinity in deep tubewells in Munshiganj District, Bangladesh," Applied Geochemistry, vol. 26, no. 7, pp. 1077-1085, 2011.

[122] D. Chakraborti, M. K. Sengupta, M. M. Rahman et al., “Groundwater arsenic contamination and its health effects in the Ganga-Meghna-Brahmaputra plain," Journal of Environmental Monitoring, vol. 6, no. 6, pp. 74N-83N, 2004.

[123] M. F. Ahmed, S. Ahuja, M. Alauddin et al., "Ensuring safe drinking water in Bangladesh," Science, vol. 314, no. 5806, pp. 1687$1688,2006$.

[124] M. H. Rahman and H. Ishiga, "Arsenic pollution in soil and groundwater of Bangladesh," in Proceedings of the International Conference on Energy and Environment, vol. 2, pp. 1626-1632, 2003.

[125] M. M. Rahman, B. K. Mandal, T. Roy Chowdhury et al., "Arsenic groundwater contamination and sufferings of people in North 24-Parganas, one of the nine arsenic affected districts of West Bengal, India," Journal of Environmental Science and Health A: Toxic/Hazardous Substances and Environmental Engineering, vol. 38, no. 1, pp. 25-59, 2003.

[126] F. Ahmed and M. Rahman, "Low-cost water supply technologies," in Water Supply \& Sanitation: Rural and Low Income Urban Communities, F. Ahmed and M. Rahman, Eds., pp. 407441, ITN-Bangladesh, Dhaka, Bangladesh, 2003.

[127] N. R. Warner, J. Levy, K. Harpp, and F. Farruggia, "Drinking water quality in Nepal's Kathmandu Valley: a survey and assessment of selected controlling site characteristics," Hydrogeology Journal, vol. 16, no. 2, pp. 321-334, 2008.

[128] H. B. Bennett, A. Shantz, G. Shin, M. L. Sampson, and J. S. Meschke, "Characterisation of the water quality from open and 
rope-pump shallow wells in rural Cambodia," Water Science and Technology, vol. 61, no. 2, pp. 473-479, 2010.

[129] M. M. Hira-Smith, Y. Yuan, X. Savarimuthu et al., "Arsenic concentrations and bacterial contamination in a pilot shallow dugwell program in West Bengal, India," Journal of Environmental Science and Health A: Toxic/Hazardous Substances and Environmental Engineering, vol. 42, no. 1, pp. 89-95, 2007.

[130] DPHE, National Policy for Arsenic Mitigation 2004, http://www .dphe.gov.bd/index.php? option $=$ com_content $\&$ view $=$ article $\&$ id=80\&Itemid $=85$.

[131] A. H. Smith, E. O. Lingas, and M. Rahman, "Contamination of drinking-water by arsenic in Bangladesh: a public health emergency," Bulletin of the World Health Organization, vol. 78, no. 9, pp. 1093-1103, 2003.

[132] S. A. Joya, G. Mostofa, J. Yousuf et al., "One solution to the arsenic problem: a return to surface (improved dug) wells," Journal of Health, Population and Nutrition, vol. 24, no. 3, pp. 363-375, 2006.

[133] B. A. Hoque, M. M. Hoque, T. Ahmed et al., "Demand-based water options for arsenic mitigation: an experience from rural Bangladesh," Public Health, vol. 118, no. 1, pp. 70-77, 2004.

[134] A. H. Milton, W. Smith, K. Dear et al., "A Randomised intervention trial to assess two arsenic mitigation options in Bangladesh," Journal of Environmental Science and Health A: Toxic/Hazardous Substances and Environmental Engineering, vol. 42, no. 12, pp. 1897-1908, 2007.

[135] M. F. Ahmed, S. A. J. Shamsuddin, S. G. Mahmud, H. Rashid, D. Deere, and G. Howard, Risk Assessment of Arsenic Mitigation Options (RAAMO), APSU, Dhaka, Bangladesh, 2005.

[136] H. Yokota, K. Tanabe, M. Sezaki et al., "Arsenic contamination of ground and pond water and water purification system using pond water in Bangladesh," Engineering Geology, vol. 60, no. 1'4, pp. 323-331, 2001.

[137] DPHE, Union Wise Water Technology Mapping [Dhaka Circle], vol. 1, DPHE Publication, Dhaka, Bangladesh, 2008.

[138] M. A. Islam, H. Sakakibara, M. R. Karim, M. Sekine, and Z. H. Mahmud, "Bacteriological assessment of drinking water supply options in coastal areas of Bangladesh," Journal of Water and Health, vol. 9, no. 2, pp. 415-428, 2011.

[139] M. R. Karim, "Microbial contamination and associated health burden of rainwater harvesting in Bangladesh," Water Science and Technology, vol. 61, no. 8, pp. 2129-2135, 2010.

[140] P. H. Masscheleyn, R. D. Delaune, and W. H. Patrick Jr., "Effect of redox potential and $\mathrm{pH}$ on arsenic speciation and solubility in a contaminated soil," Environmental Science and Technology, vol. 25, no. 8, pp. 1414-1419, 1991.

[141] G. Ghurye and D. Clifford, "As(III) oxidation using chemical and solid-phase oxidants," Jornal of American Water Works Association, vol. 96, no. 1, pp. 84-96, 2004.

[142] O. X. Leupin and S. J. Hug, "Oxidation and removal of arsenic (III) from aerated groundwater by filtration through sand and zero-valent iron," Water Research, vol. 39, no. 9, pp. 1729-1740, 2005.

[143] Y. Lee, I.-H. Um, and J. Yoon, "Arsenic (III) oxidation by iron(VI) (ferrate) and subsequent removal of arsenic (V) by iron (III) coagulation," Environmental Science and Technology, vol. 37, no. 24, pp. 5750-5756, 2003.

[144] M. C. Dodd, N. D. Vu, A. Ammann et al., "Kinetics and mechanistic aspects of As(III) oxidation by aqueous chlorine, chloramines, and ozone: relevance to drinking water treatment," Environmental Science and Technology, vol. 40, no. 10, pp. 32853292, 2006.
[145] S. Bajpai and M. Chaudhuri, "Removal of arsenic from ground water by manganese dioxide-coated sand," Journal of Environmental Engineering, vol. 125, no. 8, pp. 782-784, 1999.

[146] A. Criscuoli, S. Majumdar, A. Figoli et al., "As(III) oxidation by $\mathrm{MnO}_{2}$ coated PEEK-WC nanostructured capsules," Journal of Hazardous Materials, vol. 211-212, pp. 281-287, 2012.

[147] S.-H. Yoon and J. H. Lee, "Oxidation mechanism of As (III) in the $\mathrm{UV} / \mathrm{TiO}_{2}$ system: evidence for a direct whole oxidation mechanism," Environmental Science and Technology, vol. 39, no. 24, pp. 9695-9701, 2005.

[148] V. K. Sharma, P. K. Dutta, and A. K. Ray, "Review of kinetics of chemical and photocatalytical oxidation of Arsenic(III) as influenced by $\mathrm{pH}$," Journal of Environmental Science and Health, vol. 42, no. 7, pp. 997-1004, 2007.

[149] P. K. Dutta, A. K. Ray, V. K. Sharma, and F. J. Millero, "Adsorption of arsenate and arsenite on titanium dioxide suspensions," Journal of Colloid and Interface Science, vol. 278, no. 2, pp. 270275, 2004.

[150] S. M. Miller, M. L. Spaulding, and J. B. Zimmerman, "Optimization of capacity and kinetics for a novel bio-based arsenic sorbent, $\mathrm{TiO}_{2}$-impregnated chitosan bead," Water Research, vol. 45, no. 17, pp. 5745-5754, 2011.

[151] S. M. Miller and J. B. Zimmerman, "Novel, bio-based, photoactive arsenic sorbent: $\mathrm{TiO}_{2}$-impregnated chitosan bead," Water Research, vol. 44, no. 19, pp. 5722-5729, 2010.

[152] J. S. Yamani, S. M. Miller, M. L. Spaulding, and J. B. Zimmerman, "Enhanced arsenic removal using mixed metal oxide impregnated chitosan beads," Water Research, vol. 46, no. 14, pp. 4427-4434, 2012.

[153] M. E. Pena, G. P. Korfiatis, M. Patel, L. Lippincott, and X. Meng, "Adsorption of As(V) and As(III) by nanocrystalline titanium dioxide," Water Research, vol. 39, no. 11, pp. 2327-2337, 2005.

[154] S. Bang, M. Patel, L. Lippincott, and X. Meng, "Removal of arsenic from groundwater by granular titanium dioxide adsorbent," Chemosphere, vol. 60, no. 3, pp. 389-397, 2005.

[155] M. A. Ferguson and J. G. Hering, " $\mathrm{TiO}_{2}$-photocatalyzed As(III) oxidation in a fixed-bed, flow-through reactor," Environmental Science and Technology, vol. 40, no. 13, pp. 4261-4267, 2006.

[156] X. Guan, J. Du, X. Meng, Y. Sun, B. Sun, and Q. Hu, “Corrigendum to "Application of titanium dioxide in arsenic removal from water: a review',' Journal of Hazardous Materials, vol. 221222, p. 303, 2012.

[157] T. S. Y. Choong, T. G. Chuah, Y. Robiah, F. L. Gregory Koay, and I. Azni, "Arsenic toxicity, health hazards and removal techniques from water: an overview," Desalination, vol. 217, no. 1-3, pp. 139-166, 2007.

[158] L. S. McNeill and M. Edwards, "Soluble arsenic removal at water treatment plants," Journal of American Water Works Association, vol. 87, no. 4, pp. 105-113, 1995.

[159] V. Pallier, G. Feuillade-Cathalifaud, B. Serpaud, and J.-C. Bollinger, "Effect of organic matter on arsenic removal during coagulation/flocculation treatment," Journal of Colloid and Interface Science, vol. 342, no. 1, pp. 26-32, 2010.

[160] C. Hu, H. Liu, G. Chen, and J. Qu, "Effect of aluminum speciation on arsenic removal during coagulation process," Separation and Purification Technology, vol. 86, pp. 35-40, 2012.

[161] M. Bilici Baskan and A. Pala, "A statistical experiment design approach for arsenic removal by coagulation process using aluminum sulfate," Desalination, vol. 254 , no. 1-3, pp. 42-48, 2010. 
[162] S. Song, A. Lopez-Valdivieso, D. J. Hernandez-Campos, C. Peng, M. G. Monroy-Fernandez, and I. Razo-Soto, "Arsenic removal from high-arsenic water by enhanced coagulation with ferric ions and coarse calcite," Water Research, vol. 40, no. 2, pp. 364$372,2006$.

[163] H. A. Andrianisa, A. Ito, A. Sasaki, J. Aizawa, and T. Umita, "Biotransformation of arsenic species by activated sludge and removal of bio-oxidised arsenate from wastewater by coagulation with ferric chloride," Water Research, vol. 42, no. 19, pp. 4809-4817, 2008.

[164] D. Lakshmanan, D. A. Clifford, and G. Samanta, "Comparative study of arsenic removal by iron using electrocoagulation and chemical coagulation," Water Research, vol. 44, no. 19, pp. 56415652, 2010.

[165] E. Lacasa, P. Cañizares, C. Sáez, F. J. Fernández, and M. A. Rodrigo, "Removal of arsenic by iron and aluminium electrochemically assisted coagulation," Separation and Purification Technology, vol. 79, no. 1, pp. 15-19, 2011.

[166] D. Mohan and C. U. Pittman Jr., "Arsenic removal from water/wastewater using adsorbents-a critical review," Journal of Hazardous Materials, vol. 142, no. 1-2, pp. 1-53, 2007.

[167] J. A. Wilkie and J. G. Hering, "Adsorption of arsenic onto hydrous ferric oxide: effects of adsorbate/adsorbent ratios and co-occurring solutes," Colloids and Surfaces A: Physicochemical and Engineering Aspects, vol. 107, pp. 97-110, 1996.

[168] K. P. Raven, A. Jain, and R. H. Loeppert, "Arsenite and arsenate adsorption on ferrihydrite: kinetics, equilibrium, and adsorption envelopes," Environmental Science and Technology, vol. 32, no. 3, pp. 344-349, 1998.

[169] M. Grafe, M. J. Eick, and P. R. Grossl, "Adsorption of arsenate (V) and arsenite (III) on goethite in the presence and absence of dissolved organic carbon," Soil Science Society of America Journal, vol. 65, no. 6, pp. 1680-1687, 2001.

[170] J. Zhu, M. Pigna, V. Cozzolino, A. G. Caporale, and A. Violante, "Higher sorption of arsenate versus arsenite on amorphous Aloxide, effect of ligands," Environmental Chemistry Letters, vol. 11, no. 3, pp. 289-294, 2013.

[171] M. Kanematsu, T. M. Young, K. Fukushi, P. G. Green, and J. L. Darby, "Arsenic(III, V) adsorption on a goethite-based adsorbent in the presence of major co-existing ions: modeling competitive adsorption consistent with spectroscopic and molecular evidence," Geochimica et Cosmochimica Acta, vol. 106, pp. 404-428, 2013.

[172] T.-F. Lin and J.-K. Wu, "Adsorption of arsenite and arsenate within activated alumina grains: equilibrium and kinetics," Water Research, vol. 35, no. 8, pp. 2049-2057, 2001.

[173] T. S. Singh and K. K. Pant, "Equilibrium, kinetics and thermodynamic studies for adsorption of As(III) on activated alumina," Separation and Purification Technology, vol. 36, no. 2, pp. 139147, 2004.

[174] D. E. Giles, M. Mohapatra, T. B. Issa, S. Anand, and P. Singh, "Iron and aluminium based adsorption strategies for removing arsenic from water," Journal of Environmental Management, vol. 92, no. 12, pp. 3011-3022, 2011.

[175] S. Kuriakose, T. S. Singh, and K. K. Pant, "Adsorption of As(III) from aqueous solution onto iron oxide impregnated activated alumina," Water Quality Research Journal of Canada, vol. 39, no. 3, pp. 258-266, 2004.

[176] S. S. Tripathy and A. M. Raichur, "Enhanced adsorption capacity of activated alumina by impregnation with alum for removal of $\mathrm{As}(\mathrm{V})$ from water," Chemical Engineering Journal, vol. 138, no. 1-3, pp. 179-186, 2008.
[177] S. Kunzru and M. Chaudhuri, "Manganese amended activated alumina for adsorption/oxidation of arsenic," Journal of Environmental Engineering, vol. 131, no. 9, pp. 1350-1353, 2005.

[178] Bamwsp, Dfid, and Wab, "Rapid Assessment of Household Level Arsenic Removal Technologies. Phase II Report,” Dhaka, 2001.

[179] S. Sarkar, J. E. Greenleaf, A. Gupta et al., "Evolution of community-based arsenic removal systems in remote villages in West Bengal, India: assessment of decade-long operation," Water Research, vol. 44, no. 19, pp. 5813-5822, 2010.

[180] M. Jekel and R. Seith, "Comparison of conventional and new techniques for the removal of arsenic in a full scale water treatment plant," Water Supply, vol. 18, no. 1-2, pp. 628-631, 2000.

[181] W. Driehaus, M. Jekel, and U. Hildebrandt, "Granular ferric hydroxide-a new adsorbent for the removal of arsenic from natural water," Journal of Water Supply: Research and Technology, vol. 47, no. 1, pp. 30-35, 1998.

[182] O. S. Thirunavukkarasu, T. Viraraghavan, and K. S. Subramanian, "Arsenic removal from drinking water using granular ferric hydroxide," Water SA, vol. 29, no. 2, pp. 161-170, 2003.

[183] M. Badruzzaman, P. Westerhoff, and D. R. U. Knappe, "Intraparticle diffusion and adsorption of arsenate onto granular ferric hydroxide (GFH)," Water Research, vol. 38, no. 18, pp. 4002-4012, 2004.

[184] X.-H. Guan, J. Wang, and C. C. Chusuei, "Removal of arsenic from water using granular ferric hydroxide: macroscopic and microscopic studies," Journal of Hazardous Materials, vol. 156, no. 1-3, pp. 178-185, 2008.

[185] AIIH, "Arsenic mitigation programme for technology and park on arsenic removal devices," in Convenor Director, B. B. Basu, Ed., School of Fundamental Research, Kolkata, India, 2001.

[186] I. A. Katsoyiannis, T. Ruettimann, and S. J. Hug, "pH dependence of fenton reagent generation and As(III) oxidation and removal by corrosion of zero valent iron in aerated water," Environmental Science and Technology, vol. 42, no. 19, pp. 74247430, 2008.

[187] S. Klas and D. W. Kirk, "Advantages of low $\mathrm{pH}$ and limited oxygenation in arsenite removal from water by zero-valent iron," Journal of Hazardous Materials, vol. 252-253, pp. 77-82, 2013.

[188] A. H. Khan, S. B. Rasul, A. K. M. Munir et al., "Appraisal of a simple arsenic removal method for groundwater of Bangladesh," Journal of Environmental Science and Health A: Toxic/Hazardous Substances and Environmental Engineering, vol. 35, no. 7, pp. 1021-1041, 2000.

[189] M. Alauddin, A. Hussam, A. H. Khan, M. Habibuddowla, S. B. Rasul, and A. K. M. Munir, "Critical evaluation of a simple arsenic removal method for groundwater of Bangladesh," in Arsenic Exposure and Health Effects IV. 4th International Conference on Arsenic Exposure and Health Effects, pp. 441-451, San Diego, Calif, USA, June 2001.

[190] A. Hussam and A. K. M. Munir, "A simple and effective arsenic filter based on composite iron matrix: development and deployment studies for groundwater of Bangladesh," Journal of Environmental Science and Health A Toxic/Hazardous Substances and Environmental Engineering, vol. 42, no. 12, pp. 18691878, 2007.

[191] H. Chiew, M. L. Sampson, S. Huch, S. Ken, and B. C. Bostick, "Effect of groundwater iron and phosphate on the efficacy of arsenic removal by iron-amended bios and filters," Environmental Science and Technology, vol. 43, no. 16, pp. 6295-6300, 2009. 
[192] A. Neumann, R. Kaegi, A. Voegelin, A. Hussam, A. K. M. Munir, and S. J. Hug, "Arsenic removal with composite iron matrix filters in Bangladesh: a field and laboratory study," Environmental Science and Technology, vol. 47, no. 9, pp. 45444554, 2013.

[193] C. Noubactep, "Metallic iron for water treatment: a critical review," Clean-Soil, Air, Water, vol. 41, no. 7, pp. 702-710, 2013.

[194] S. Tresintsi, K. Simeonidis, G. Vourlias, G. Stavropoulos, and M. Mitrakas, "Kilogram-scale synthesis of iron oxy-hydroxides with improved arsenic removal capacity: study of Fe(II) oxidation-precipitation parameters," Water Research, vol. 46, no. 16, pp. 5255-5267, 2012.

[195] T. Zhang and D. D. Sun, "Removal of arsenic from water using multifunctional micro-/nano-structured $\mathrm{MnO}_{2}$ spheres and microfiltration," Chemical Engineering Journal, vol. 225, pp. 271-279, 2013.

[196] H. Cui, Y. Su, Q. Li, S. Gao, and J. K. Shang, "Exceptional arsenic $(\mathrm{III}, \mathrm{V})$ removal performance of highly porous, nanostructured $\mathrm{ZrO}_{2}$ spheres for fixed bed reactors and the full-scale system modeling," Water Research, 2013.

[197] M. Cui, M. Jang, S. Ibrahim, B. Park, E. Cho, and J. Khim, "Arsenite removal using a pilot system of ultrasound and ultraviolet followed by microfiltration," Ultrasonics Sonochemistry, vol. 21, pp. 1527-1534, 2014.

[198] S. Silver and L. T. Phung, "Genes and enzymes involved in bacterial oxidation and reduction of inorganic arsenic," Applied and Environmental Microbiology, vol. 71, no. 2, pp. 599-608, 2005.

[199] A. M. Laverman, J. S. Blum, J. K. Schaefer, E. J. P. Phillips, D. R. Lovley, and R. S. Oremland, "Growth of strain SES-3 with arsenate and other diverse electron acceptors," Applied and Environmental Microbiology, vol. 61, no. 10, pp. 3556-3561, 1995.

[200] J. M. Macy, J. M. Santini, B. V. Pauling, A. H. O’Neill, and L. I. Sly, "Two new arsenate/sulfate-reducing bacteria: mechanisms of arsenate reduction," Archives of Microbiology, vol. 173, no. 1, pp. 49-57, 2000.

[201] R. S. Oremland and J. F. Stolz, "Arsenic, microbes and contaminated aquifers," Trends in Microbiology, vol. 13, no. 2, pp. 45-49, 2005.

[202] R. S. Oremland, C. W. Saltikov, F. Wolfe-Simon, and J. F. Stolz, "Arsenic in the evolution of earth and extraterrestrial ecosystems," Geomicrobiology Journal, vol. 26, no. 7, pp. 522536, 2009.

[203] M. R. Jekel, "Removal of arsenic in drinking water treatment," in Arsenic in the Environment. Part 1: Cycling and Characterization, J. O. Nriagu, Ed., pp. 119-130, Wiley, New York, NY, USA, 1994.

[204] . Molnar L, E. Vircikova, and P. Lech, "Experimental study of $\mathrm{As}^{I I I}$ oxidation by hydrogen peroxide," Hydrometallurgy, vol. 35, pp. 1-7, 1994.

[205] M.-J. Kim and J. Nriagu, "Oxidation of arsenite in groundwater using ozone and oxygen," Science of the Total Environment, vol. 247, no. 1, pp. 71-79, 2000.

[206] H. Gallard and U. Von Gunten, "Chlorination of natural organic matter: kinetics of chlorination and of THM formation," Water Research, vol. 36, no. 1, pp. 65-74, 2002.

[207] I. A. Katsoyiannis, A. I. Zouboulis, and M. Jekel, "Kinetics of bacterial As(III) oxidation and subsequent As(V) removal by sorption onto biogenic manganese oxides during groundwater treatment," Industrial and Engineering Chemistry Research, vol. 43, no. 2, pp. 486-493, 2004.
[208] F. Battaglia-Brunet, M.-C. Dictor, F. Garrido et al., "An arsenic(III)-oxidizing bacterial population: selection, characterization, and performance in reactors," Journal of Applied Microbiology, vol. 93, no. 4, pp. 656-667, 2002.

[209] J. M. Santini, L. I. Sly, R. D. Schnagl, and J. M. Macy, "A new chemolithoautotrophic arsenite-oxidizing bacterium isolated from a gold mine: phylogenetic, physiological, and preliminary biochemical studies," Applied and Environmental Microbiology, vol. 66, no. 1, pp. 92-97, 2000.

[210] E. O. Kartinen Jr. and C. J. Martin, "An overview of arsenic removal processes," Desalination, vol. 103, no. 1-2, pp. 79-88, 1995.

[211] A. I. Zouboulis and I. A. Katsoyiannis, "Arsenic removal using iron oxide loaded alginate beads," Industrial \& Engineering Chemistry Research, vol. 41, no. 24, pp. 6149-6155, 2002.

[212] I. Katsoyiannis, A. Zouboulis, H. Althoff, and H. Bartel, "As(III) removal from groundwaters using fixed-bed upflow bioreactors," Chemosphere, vol. 47, no. 3, pp. 325-332, 2002.

[213] I. A. Katsoyiannis and A. I. Zouboulis, "Application of biological processes for the removal of arsenic from groundwaters," Water Research, vol. 38, no. 1, pp. 17-26, 2004.

[214] I. A. Katsoyiannis, A. Zikoudi, and S. J. Hug, "Arsenic removal from groundwaters containing iron, ammonium, manganese and phosphate: a case study from a treatment unit in Northern Greece," Desalination, vol. 224, no. 1-3, pp. 330-339, 2008.

[215] I. A. Katsoyiannis, A. I. Zouboulis, M. Mitrakas, H. W. Althoff, and H. Bartel, "A hybrid system incorporating a pipe reactor and microfiltration for biological iron, manganese and arsenic removal from anaerobic groundwater," Fresenius Environmental Bulletin, vol. 22, pp. 3848-2853, 2013.

[216] D. K. Nordstrom, "Worldwide occurrences of arsenic in ground water," Science, vol. 296, no. 5576, pp. 2143-2145, 2002.

[217] O. Gunduz, C. Simsek, and A. Hasozbek, "Arsenic pollution in the groundwater of Simav Plain, Turkey: its impact on water quality and human health," Water, Air, \& Soil Pollution, vol. 205, no. 1-4, pp. 43-62, 2010.

[218] J. Bundschuh, M. I. Litter, F. Parvez et al., "One century of arsenic exposure in Latin America: a review of history and occurrence from 14 countries," Science of the Total Environment, vol. 429, pp. 2-35, 2012.

[219] M. M. Rahman, R. Naidu, and P. Bhattacharya, "Arsenic contamination in groundwater in the Southeast Asia region," Environmental Geochemistry and Health, vol. 31, no. 1, pp. 9-21, 2009.

[220] S. Das, J.-S. Jean, and S. Kar, "Bioaccessibility and health risk assessment of arsenic in arsenic-enriched soils, Central India," Ecotoxicology and Environmental Safety, vol. 92, pp. 252-257, 2013.

[221] S. Srivastava and Y. K. Sharma, "Arsenic occurrence and accumulation in soil and water of eastern districts of Uttar Pradesh, India," Environmental Monitoring and Assessment, vol. 185, no. 6, pp. 4995-5002, 2013.

[222] M. M. Rahman, R. Naidu, and P. Bhattacharya, "Arsenic contamination in groundwater in the Southeast Asia region," Environmental Geochemistry and Health, vol. 31, supplement 1, pp. 9-21, 2009. 
[223] N. K. C. Twarakavi and J. J. Kaluarachchi, "Arsenic in the shallow ground waters of conterminous United States: assessment, health risks, and costs for MCL compliance," Journal of the American Water Resources Association, vol. 42, no. 2, pp. 275294, 2006.

[224] Q. M. Lena, S. Hong-Jie, R. Bala, W. Bing, L. Jun, and P. Li-Ping, "Arsenic and selenium toxicity and their interactive effects in humans," Environment International, vol. 69, pp. 148-158, 2014. 

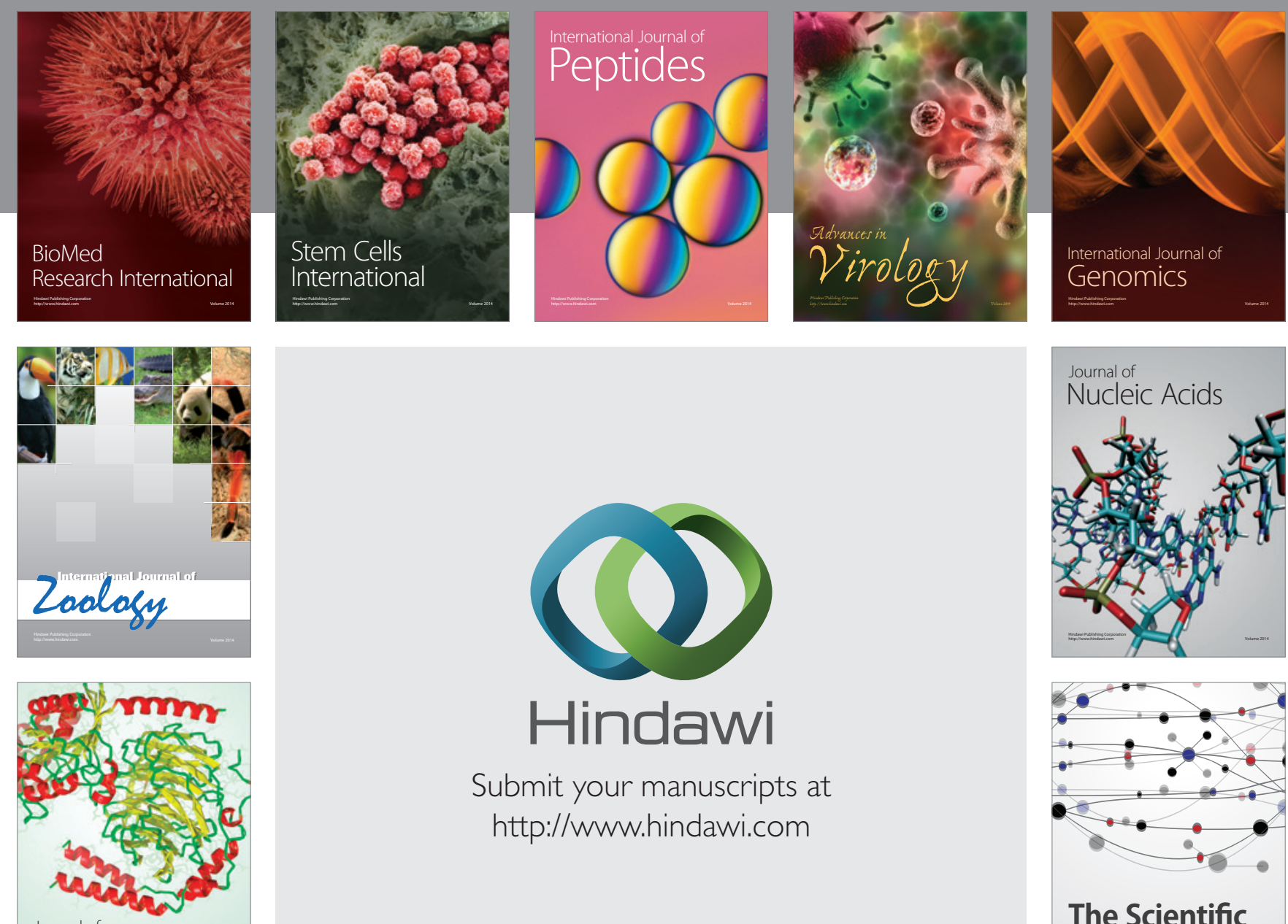

Submit your manuscripts at

http://www.hindawi.com

Journal of
Signal Transduction
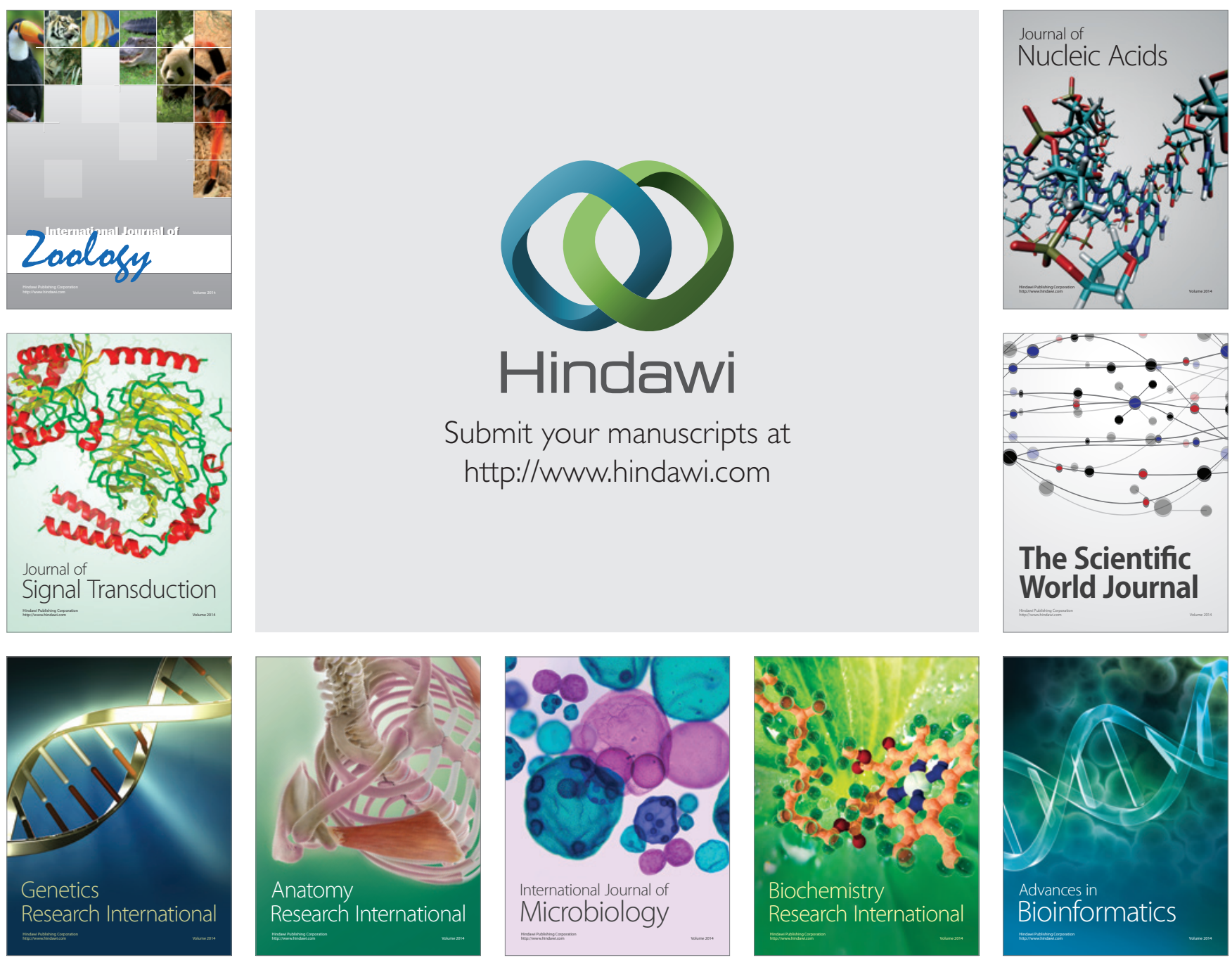

The Scientific World Journal
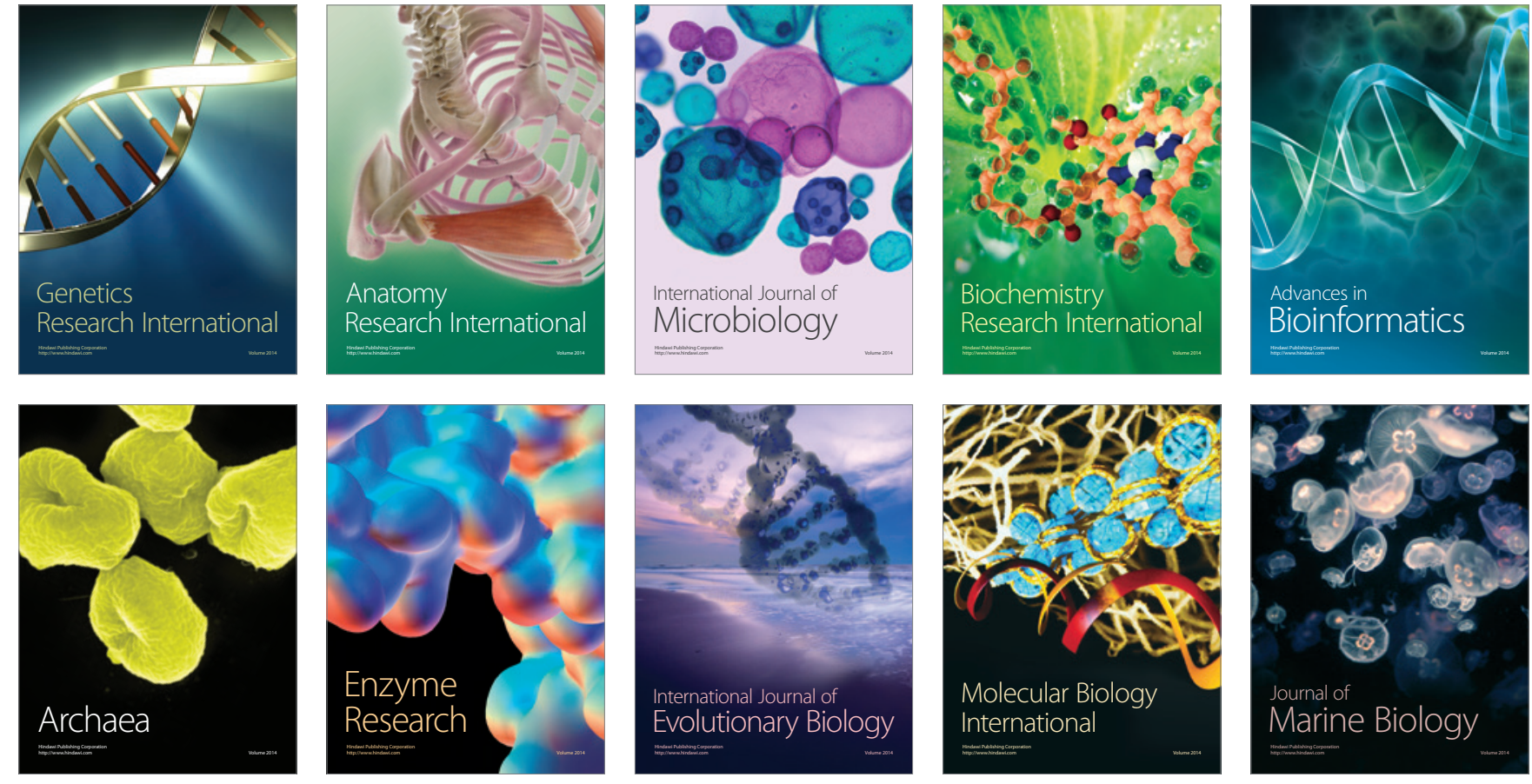